\title{
Modelling of soil characteristics as basis for projections of potential future forest ecosystem development under climate change and atmospheric nitrogen deposition
}

\author{
Angela Schlutow ${ }^{1}$, Winfried Schröder ${ }^{2^{*}} \mathbb{0}$, Martin Jenssen ${ }^{2}$ and Stefan Nickel $^{2}$
}

\begin{abstract}
Background: The EU Biodiversity Strategy to 2020 foresees that Member States assess conditions and potential developments of ecosystems under climate change and atmospheric nitrogen deposition. This combination of environmental impacts has never been modelled for the German territory before. Therefore, the aim of the presented dynamic modelling of soil parameters under the influence of changing atmospheric nitrogen deposition with simultaneous climate change at representative sites in Germany was to derive knowledge about the expected development of ecosystem conditions up to a possible change of the respective site-specific current ecosystem type. The dynamic modelling was performed with the Very Simple Dynamic soil model. The selection of 15 modelling sites regarded the availability of data from environmental monitoring programmes routinely operated by public institutions and the aptitude of data for parametrising the soil model. The most important input data are time series of nitrogen and acid deposition as well as time series of the relevant climatic-ecological parameters. The simulation period covered the years 1920-2070.

Results: There are no continuous linear correlations between the level of acidifying or eutrophying inputs and the course of soil parameter values. The step-like courses result from the resilience of the ecosystems within certain parameter ranges. Atmospheric nitrogen deposition has led to nitrogen saturation at 14 of 15 sites selected for modelling. Currently, no linear (negative) correlation between nitrogen deposition and carbon/nitrogen ratio could be established at these sites any more. An increase in the N-content in the soil was only slight, if at all. On the other hand, the nitrate concentration in the leachate increases in correlation to the $\mathrm{N}$ deposition. A clear (negative) correlation was found for the dependence of the $\mathrm{C} / \mathrm{N}$ ratio on the temperature development in connection with climate change. The predicted air temperature rise until 2070 will also cause a decrease of the carbon content in the future, caused by the increasing activity of decomposing soil organisms. Thus, the drastic decrease of the $\mathrm{C} / \mathrm{N}$ ratio at all of the study sites is due to the significant decrease in the $\mathrm{C}$ content. The validation shows that the dynamic modelling of abiotic site parameters has delivered plausible results at the investigated sites. The applicability of the results could be demonstrated. Thus, the evaluation of the time series of soil and climate parameters resulted in forest ecosystem types that are capable of self-regeneration in the future under the conditions of air pollutant inputs and climate change.
\end{abstract}

*Correspondence: Winfried.Schroeder@uni-vechta.de

${ }^{2}$ Chair of Landscape Ecology, University of Vechta, P.O.B. 1553,

49364 Vechta, Germany

Full list of author information is available at the end of the article

SpringerOpen

(c) The Author(s) 2021. Open Access This article is licensed under a Creative Commons Attribution 4.0 International License, which permits use, sharing, adaptation, distribution and reproduction in any medium or format, as long as you give appropriate credit to the original author(s) and the source, provide a link to the Creative Commons licence, and indicate if changes were made. The images or other third party material in this article are included in the article's Creative Commons licence, unless indicated otherwise in a credit line to the material. If material is not included in the article's Creative Commons licence and your intended use is not permitted by statutory regulation or exceeds the permitted use, you will need to obtain permission directly from the copyright holder. To view a copy of this licence, visit http://creativecommons.org/licenses/by/4.0/. 
Conclusions: The dynamic modelling of soil parameters under the influence of atmospheric nitrogen deposition and of climate change enables to transparently rank the potential development of ecosystem conditions up to a possible extinction of the current ecosystem type. Thus, the soil modelling approach presented contributes to the implementation of the European Biodiversity Strategy.

Keywords: Dynamic modelling (Very Simple Dynamics—VSD+), Ecosystem classification, Ecosystem integrity, Germany, Representative ecosystems, Statistical modelling of soil indicators from vegetation data

\section{Background and objective}

Climate change and atmospheric nitrogen $(\mathrm{N})$ deposition can impact the integrity of ecosystems, i.e. their dominant structures and functions, and thus limit their benefits for humans, the ecosystem services. The $\mathrm{N}$ cycle interacts with all ecosystem compartments, e.g. soil, plants and micro-organisms, and is very complex through various chemical forms. Therefore, nitrogen emissions, their atmospheric deposition and effects on ecosystems on terrestrial ecosystems, and particularly on forests, are well documented in literature [1-4]. Nevertheless, field experiments dealing with the impact of atmospheric $\mathrm{N}$ deposition do not enable predictions about possible future developments and the design of potential management options. Therefore, in order to model and predict the impact of atmospheric $\mathrm{N}$ deposition on forest ecosystems, and more particularly on soil biogeochemistry, modelling approaches are required [5]. De Vries et al. [6] gave an overview of the existing models and concluded among others that further testing and validation of the models against long-term monitoring or long-term experimental data sets and against large-scale survey data combining vegetation descriptions with variables affecting the species diversity, such as soil acidity, nutrient status and water availability is required.

The impact of atmospheric $\mathrm{N}$ deposition should be considered in the context of climate change since the expected temperature increase due to future climate change could also affect soil nitrogen processes. Atmospheric $\mathrm{N}$ pollution and climate change impacts on ecosystems are traditionally considered separately, whereas they have a combined effect [5]. Therefore, predict potential forest ecosystem conditions over time, climate change and atmospheric $\mathrm{N}$ deposition must both be considered, especially if biodiversity should be protected. Therefore, action 5 of the EU Biodiversity Strategy to 2020 foresees that Member States will map and assess the state of ecosystems and their services in their national territory. To this end, an operational guidance to the EU and the Member States on how to assess the condition of Europe's ecosystems was developed. Accordingly, ecosystem condition should be measured using indicators and specified for the national level of the EU member states [7]. For Germany, a methodology to identify and classify changes in ecosystem integrity due to climate change and atmospheric $\mathrm{N}$ deposition was developed [8-11] and further deepened [12]. This methodology was based on extensive vegetation and soil databases, nationwide available maps, long-term environmental monitoring programmes and results from climate change modelling. The ecosystem classification was complemented by dynamic modelling of ecological soil processes under climate change and atmospheric nitrogen deposition as essential boundary conditions for future ecosystem development and services. Since such modelling is largely lacking in Germany and also in Europe, a methodological object was developed using Germany as an example, which is dealt with in this paper.

This paper is intended to combine 2 objectives: (a) validation of the forecast model at typical forest sites in Germany and (b) presentation and discussion of the interpretation possibilities of the model results up to the derivation of concrete forest conversion and management measures.

\section{Materials and methods}

Dynamic modelling of soil chemistry considers atmospheric $\mathrm{N}$ deposition in the presence of climate change. The expected future climate until the year 2070 was based on two scenarios of the STAR II climate projections (RCP 2.6 and 8.5). ${ }^{1}$ Soil modelling aimed to support projection of expected ecosystem conditions up to a potential extinction of current ecosystem types. The soil modelling was performed with VSD+ (Very Simple Dynamic Soil model) version 5.3.1 [15], CCE 2012; [16] and a meteo-hydrological pre-processor (MetHyd 1.5.1[17]) to calculate daily evapotranspiration, soil moisture, precipitation surplus and parameters related to $\mathrm{N}$ processes. MetHyd reads daily data on temperature, precipitation and radiation, or derives daily values from monthly data. MetHyd input includes information on soil hydraulic properties, as well as bulk density, the content of clay, sand and organic carbon for 15 forest sites which each represent one ecosystem type and ecologically defined region ("Modelling sites" section).

\footnotetext{
${ }^{1}$ Statistical Regional climate model [13], Representative Concentration Pathways [14].
} 


\section{Modelling sites}

The modelling sites (Fig. 1) were selected according to their representativity for ecosystem and soil types and their spatial coverage across Germany [18] as well as according to the data availability for the dynamic modelling of future soil conditions. The data available for the sites selected were as complete as possible for the parameterisation and calibration of the model and covers longterm measurements. Furthermore, data from vegetation surveys at each site selected were necessary and therefore integrated into the modelling in order to enable modelling with vegetation-related indicator values (e.g. for soil moisture, nutrient supply). The data used and the characteristic modelling sites are specified in "Modelling data and specifications" section and in Additional file 1.

\section{Modelling data and specifications}

The dynamic modelling uses reference values from the period 1920-1960 (database "Bioindication for Ecosystem Regeneration towards natural conditions, BERN", [19]) which were then used to validate the period 19611990 covered by the W.I.E. soil and vegetation database. The site-specific input data for VSD+ modelling are presented in Additional file 2 ([12], vol. 1: Appendix A.2; [20]). From the time series of relevant climate data and pollutant inputs, compiled both retrospectively and prognostically, the values at exemplary years are included in Table 1.

Measured values of $\mathrm{pH}, \mathrm{C} / \mathrm{N}$ ratio, and base saturation from at least 1 year were available as annual averages for all sites. The VSD + model run was calibrated against these measured values. Thus, a comparison of modelled and measured values for validation of the model values does not make sense.

\section{Results}

\section{Overview}

This section presents an overview of the results of the dynamic modelling of soil chemical parameters such as carbon stock (total $\mathrm{C}$ pool), $\mathrm{N}$ stock (total $\mathrm{N}$ pool), $\mathrm{C} / \mathrm{N}$ ratio (average soil $\mathrm{C}: \mathrm{N}$ ratio), $\mathrm{pH}\left(\mathrm{H}_{2} \mathrm{O}\right)$ value $(\mathrm{pH})$, aluminium/base ratio $(\mathrm{Al} /(\mathrm{Ca}+\mathrm{Mg}+\mathrm{K})$ ratio) and base saturation $(\mathrm{EBC})$ as a function of the historical and predicted development of atmospheric deposition (S_dep, NOx_dep, NH3_dep, Ca_dep, Mg_dep, K_dep), two forecast $\mathrm{N}$-scenarios $(5 \mathrm{~kg} ; 15 \mathrm{~kg}$ ) as well as implementing two forecast scenarios (RCP 2.6; RCP 8.5) of the leachate rate (precipitation surplus) under the influence of climate change. The modelled time series thus show trends and possible developments on the basis of predefined scenarios. Additional file 4: Figures S1-S14 depict all model results for 1920 to 2070. Sites measurments are given as blue crosses. Table 2 lists the results of the modelling. For modelling site 1, "Results exemplified by ICP Forests Level II Site 606" section exemplarily presents the respective findings. "Relevance of modelling results for the projection of possible future ecosystem conditions and for related forest management options" section contains suggestions for potential future forest management options.

\section{Results exemplified by ICP Forests Level II Site 606}

The simulated time series for this site are shown in Fig. 2 in connection with Table 3 .

Model results are shown in Table 2. From 1920 onwards, the $\mathrm{S}$ deposition rose from 0.74 to $1.13 \mathrm{keq} \mathrm{S} \mathrm{ha} \mathrm{h}^{-1} \mathrm{a}^{-1}$ in 1940 and then dropped to $0.5 \mathrm{keq} \mathrm{S} \mathrm{ha}^{-1} \mathrm{a}^{-1}$ by 1945 . The $\mathrm{N}$ deposition was rather constant at $1.1 \mathrm{keq} \mathrm{N} \mathrm{ha}^{-1} \mathrm{a}^{-1}$ until 1945, after which there was a moderate increase in sulphur deposition from 0.5 to $2.2 \mathrm{keq} \mathrm{S} \mathrm{ha}^{-1} \mathrm{a}^{-1}$ between 1945 and 1980, while atmospheric $\mathrm{N}$ deposition increased massively from 1.1 to $2.4 \mathrm{keq} \mathrm{N} \mathrm{ha}^{-1} \mathrm{a}^{-1}$ during this period. As a result of the simultaneously acidifying and eutrophicating effect of the very high $\mathrm{N}$ deposition, the $\mathrm{pH}$ dropped from 7.1 to 6.4 from 1920 to 1980 and the base saturation from 99 to $95 \%$. Since the parent material was naturally very rich in bases, a high release rate of basic cations through weathering of the substrate effectively counteracts acidification. The carbonate buffer area was not abandoned, so that no aluminium ions are released. $\mathrm{The} \mathrm{Al} /(\mathrm{Ca}+\mathrm{Mg}+\mathrm{K})$ ratio has therefore remained constant at an extremely low level. The $\mathrm{N}$ deposition caused a slight increase in the $\mathrm{N}$ inventory. High $\mathrm{N}$ inputs in the 1980 s, coupled with rising temperatures and a consistently good base and water supply, accelerate the mineralisation of litterfall and thus the release of $\mathrm{CO}_{2}$ from the humus layers. The $\mathrm{C}$ content in the soil decreases. However, the simultaneous decrease of the $C$ stock caused a significant decrease of the $\mathrm{C} / \mathrm{N}$ ratio from 18.5 to 14.6 in the period from 1920 to 1980 . However, both values still lie within the typical range for the humus class mull which corresponds to both the reference condition and the current condition. From 1980

(See figure on next page.)

Fig. 1 Geographical locations of the 5 modelling regions and 15 modelling sites. BDF=Long-term soil monitoring; BÜK= reference soil profile of the land use-specified soil map 1:1,000,000 Germany (BÜK1000N); Level II= monitoring site of the International Cooperative Programme on Assessment and Monitoring of Air Pollution Effects on Forests, Level II (ICP Forests); LII 1202 was at the same time the site of the International Cooperative Programme on Integrated Monitoring of Air Pollution Effects on Ecosystems (ICP IM) 


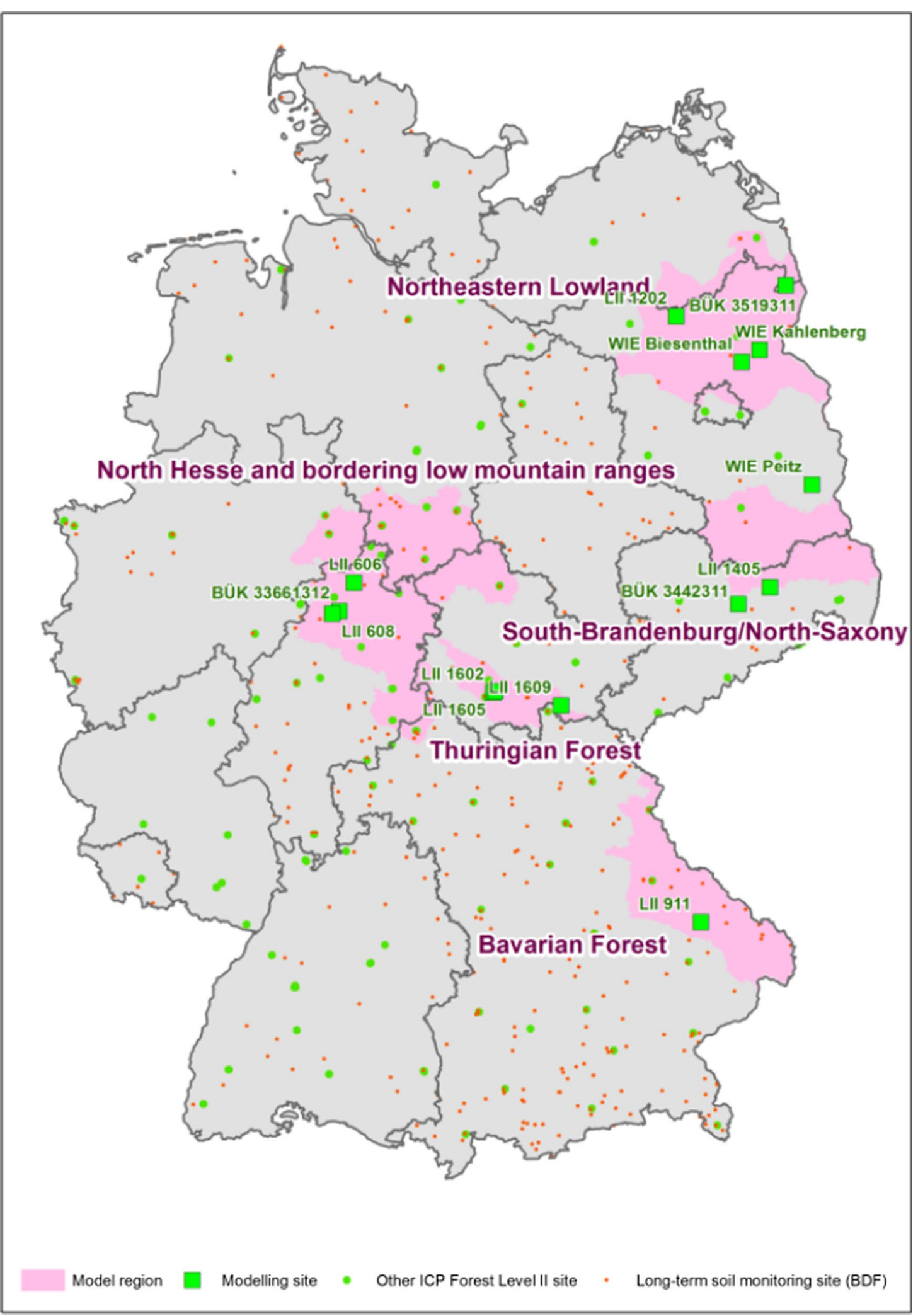

Fig. 1 (See legend on previous page.) 
Table 1 Input data for modelling soil processes at 15 sites in Germany for exemplary years

\begin{tabular}{|c|c|c|c|c|c|c|c|}
\hline & 1920 & 1985 & 2009 & $\begin{array}{l}2070 \\
\text { RCP2.6_5 kg N }\end{array}$ & $\begin{array}{l}2070 \\
\text { RCP2.6_15 kg N }\end{array}$ & $\begin{array}{l}2070 \\
\text { RCP8.5_5 kg N }\end{array}$ & $\begin{array}{l}2070 \\
\text { RCP8.5_15 kg N }\end{array}$ \\
\hline \multicolumn{8}{|c|}{ ICP Forests LII-606 calciphilous mull beech forests (Eb-5n-E2) } \\
\hline $\mathrm{T}\left({ }^{\circ} \mathrm{C}\right)$ & & & 8.3 & 9.3 & 9.3 & 12.8 & 12.8 \\
\hline $\mathrm{PS}\left(\mathrm{mm} \mathrm{a}^{-1}\right)$ & & 148 & 146 & 68 & 68 & 12 & 12 \\
\hline Sdep (keq ha $\left.{ }^{-1} \mathrm{a}^{-1}\right)$ & 0.74 & 2.2 & 0.3 & 0.3 & 0.3 & 0.3 & 0.3 \\
\hline $\operatorname{Ndep}\left(\right.$ keq ha $\left.a^{-1} a^{-1}\right)$ & 1.1 & 2.4 & 1.1 & 0.36 & 1.07 & 0.36 & 1.07 \\
\hline \multicolumn{8}{|c|}{ ICP Forests LII-608 moder beech forests of the montane level (D1-5n-C2) } \\
\hline $\mathrm{T}\left({ }^{\circ} \mathrm{C}\right)$ & & & 8 & 9.5 & 9.5 & 12 & 12 \\
\hline $\mathrm{PS}\left(\mathrm{mm} \mathrm{a}^{-1}\right)$ & & 90 & 172 & 96 & 96 & 99 & 99 \\
\hline Sdep (keq ha $\left.{ }^{-1} a^{-1}\right)$ & 0.71 & 2.2 & 0.3 & 0.3 & 0.3 & 0.3 & 0.3 \\
\hline $\operatorname{Ndep}\left(k e q h^{-1} a^{-1}\right)$ & 1 & 2.2 & 1.1 & 0.36 & 1.07 & 0.36 & 1.07 \\
\hline \multicolumn{8}{|c|}{ ICP Forests LII-911 moder beech forests with fir of the montane level (C1-6d-B2) } \\
\hline $\mathrm{PS}\left(\mathrm{mm} \mathrm{a}^{-1}\right)$ & & 752 & 999 & 540 & 540 & 409 & 409 \\
\hline Sdep (keq ha $\left.{ }^{-1} a^{-1}\right)$ & 1.02 & 3.2 & 0.34 & 0.34 & 0.34 & 0.34 & 0.34 \\
\hline Ndep $\left(\right.$ keq ha $\left.a^{-1} a^{-1}\right)$ & 1.25 & 2.8 & 1.45 & 0.36 & 1.07 & 0.36 & 1.07 \\
\hline \multicolumn{8}{|c|}{ ICP Forests LII-1202 mor humus pine forests (Ebc-4n-c1) } \\
\hline $\mathrm{PS}\left(\mathrm{mm} \mathrm{a}^{-1}\right)$ & & 141 & 234 & 176 & 176 & 117 & 117 \\
\hline Sdep (keq ha $\left.{ }^{-1} a^{-1}\right)$ & 0.9 & 2.5 & 0.31 & 0.31 & 0.31 & 0.31 & 0.31 \\
\hline Ndep (keq ha $\left.{ }^{-1} a^{-1}\right)$ & 0.8 & 1.8 & 0.9 & 0.36 & 1.07 & 0.36 & 1.07 \\
\hline \multicolumn{8}{|c|}{ ICP IM Neuglobsow mor humus beech forests with pine (Eb-4n-B2) } \\
\hline $\mathrm{T}\left({ }^{\circ} \mathrm{C}\right)$ & & & 7.9 & 8.8 & 8.8 & 11.8 & 11.8 \\
\hline $\mathrm{PS}\left(\mathrm{mm} \mathrm{a}^{-1}\right)$ & & 141 & 234 & 176 & 176 & 117 & 117 \\
\hline Sdep (keq ha $\left.{ }^{-1} \mathrm{a}^{-1}\right)$ & 0.9 & 2.5 & 0.31 & 0.31 & 0.31 & 0.31 & 0.31 \\
\hline Ndep (keq ha $\left.{ }^{-1} a^{-1}\right)$ & 0.8 & 1.8 & 0.9 & 0.36 & 1.07 & 0.36 & 1.07 \\
\hline \multicolumn{8}{|c|}{ BÜK 33_61_31 Moder pine forests (Eb-4n-C2) } \\
\hline $\mathrm{T}\left({ }^{\circ} \mathrm{C}\right)$ & & & 8 & 9.5 & 9.5 & 12 & 12 \\
\hline $\mathrm{PS}\left(\mathrm{mm} \mathrm{a}^{-1}\right)$ & & 90 & 172 & 96 & 96 & 99 & 99 \\
\hline Sdep (keq ha $\left.{ }^{-1} \mathrm{a}^{-1}\right)$ & 0.71 & 2.2 & 0.3 & 0.3 & 0.3 & 0.3 & 0.3 \\
\hline $\operatorname{Ndep}\left(\right.$ keq ha $\left.a^{-1} a^{-1}\right)$ & 1 & 2.2 & 1.1 & 0.36 & 1.07 & 0.36 & 1.07 \\
\hline \multicolumn{8}{|c|}{ BÜK 34_42_31 Moder hornbeam forests with small-leaved lime (Eb-5n-D1) } \\
\hline $\mathrm{T}\left({ }^{\circ} \mathrm{C}\right)$ & & & 8.7 & 9.1 & 9.1 & 9.3 & 9.3 \\
\hline $\mathrm{PS}\left(\mathrm{mm} \mathrm{a}^{-1}\right)$ & & 31 & 31 & 31 & 31 & 27 & 27 \\
\hline Sdep (keq ha $\left.{ }^{-1} \mathrm{a}^{-1}\right)$ & 1.8 & 5.8 & 0.62 & 0.62 & 0.62 & 0.62 & 0.62 \\
\hline $\operatorname{Ndep}\left(\right.$ keq ha $\left.a^{-1} a^{-1}\right)$ & 1.18 & 2.67 & 1.2 & 0.36 & 1.07 & 0.36 & 1.07 \\
\hline \multicolumn{8}{|c|}{ BÜK 35_19_31 Loamy mull beech forests (Ed-4n-C2) } \\
\hline $\mathrm{T}\left({ }^{\circ} \mathrm{C}\right)$ & & & 8 & 11.5 & 11.5 & 11.5 & 11.5 \\
\hline $\mathrm{PS}\left(\mathrm{mm} \mathrm{a}^{-1}\right)$ & & 26 & 26 & & & 25 & 25 \\
\hline Sdep (keq ha $\left.{ }^{-1} a^{-1}\right)$ & 0.92 & 2.5 & 0.46 & 0.46 & 0.46 & 0.46 & 0.46 \\
\hline $\operatorname{Ndep}\left(k e q h^{-1} a^{-1}\right)$ & 1 & 2.1 & 1.26 & 0.36 & 1.07 & 0.36 & 1.07 \\
\hline \multicolumn{8}{|c|}{ ICP Forests Level II 1405 mor humus pine forests (Eb-4n-b1) } \\
\hline $\mathrm{PS}\left(\mathrm{mm} \mathrm{a}^{-1}\right)$ & 289 & 396 & 385 & 239 & 239 & 200 & 200 \\
\hline Sdep $\left(\right.$ keq ha $\left.{ }^{-1} \mathrm{a}^{-1}\right)$ & 1.9 & 4.3 & 0.5 & 0.5 & 0.5 & 0.5 & 0.5 \\
\hline Ndep (keq ha $\left.{ }^{-1} a^{-1}\right)$ & 0.29 & 1.45 & 0.6 & 0.35 & 1.07 & 0.35 & 1.07 \\
\hline \multicolumn{8}{|c|}{ ICP Forests Level II 1602 Moder beech forests with spruce and fir of the altimontane level (C3-6d-C2) } \\
\hline $\mathrm{T}\left({ }^{\circ} \mathrm{C}\right)$ & 6.4 & 6.5 & 7.6 & 8.2 & 8.2 & 9.8 & 9.8 \\
\hline $\mathrm{PS}\left(\mathrm{mm} \mathrm{a}^{-1}\right)$ & 708 & 599 & 559 & 385 & 385 & 348 & 348 \\
\hline Sdep (keq ha ${ }^{-1} \mathrm{a}^{-1}$ ) & 1.1 & 4.07 & 0.5 & 0.47 & 0.47 & 0.47 & 0.47 \\
\hline $\operatorname{Ndep}\left(\right.$ keq ha $\left.a^{-1} a^{-1}\right)$ & 0.28 & 1.38 & 0.6 & 0.35 & 1.06 & 0.35 & 1.06 \\
\hline
\end{tabular}


Table 1 (continued)

\begin{tabular}{|c|c|c|c|c|c|c|c|}
\hline & 1920 & 1985 & 2009 & $\begin{array}{l}2070 \\
\text { RCP2.6_5 kg N }\end{array}$ & $\begin{array}{l}2070 \\
\text { RCP2.6_15 kg N }\end{array}$ & $\begin{array}{l}2070 \\
\text { RCP8.5_5 kg N }\end{array}$ & $\begin{array}{l}2070 \\
\text { RCP8.5_15 kg N }\end{array}$ \\
\hline \multicolumn{8}{|c|}{ ICP Forests Level II 1605 mor humus spruce forests of the altimontane level (C4-6d-B1) } \\
\hline $\mathrm{T}\left({ }^{\circ} \mathrm{C}\right)$ & 5.4 & 6 & 6.4 & 6.8 & 6.8 & 8.4 & 8.4 \\
\hline $\mathrm{PS}\left(\mathrm{mm} \mathrm{a}^{-1}\right)$ & 643 & 710 & 794 & 731 & 731 & 493 & 493 \\
\hline Sdep (keq ha $\left.{ }^{-1} a^{-1}\right)$ & 1.1 & 4.07 & 0.5 & 0.47 & 0.47 & 0.47 & 0.47 \\
\hline $\operatorname{Ndep}\left(\right.$ keq ha $\left.{ }^{-1} a^{-1}\right)$ & 0.27 & 1.3 & 0.6 & 0.35 & 1.06 & 0.35 & 1.06 \\
\hline \multicolumn{8}{|c|}{ ICP Forests Level II 1609 moder spruce forests of the montane level (Dg-5n-c2) } \\
\hline $\mathrm{T}\left({ }^{\circ} \mathrm{C}\right)$ & 6 & 6.1 & 7.6 & 8 & 8 & 9.6 & 9.6 \\
\hline $\mathrm{PS}\left(\mathrm{mm} \mathrm{a}^{-1}\right)$ & 512 & 471 & 393 & 353 & 353 & 303 & 303 \\
\hline Sdep (keq ha $\left.{ }^{-1} a^{-1}\right)$ & 1 & 4.6 & 0.53 & 0.5 & 0.5 & 0.5 & 0.5 \\
\hline $\operatorname{Ndep}\left(\right.$ keq ha $\left.{ }^{-1} a^{-1}\right)$ & 0.26 & 1.4 & 0.62 & 0.35 & 1.06 & 0.35 & 1.06 \\
\hline \multicolumn{8}{|c|}{ W.I.E. Biesenthal moder beech forests with sessile oak (Eb-4n-C1) } \\
\hline $\mathrm{T}\left({ }^{\circ} \mathrm{C}\right)$ & 8.2 & 8.4 & 9.4 & 9.9 & 9.9 & 11.6 & 11.6 \\
\hline $\mathrm{PS}\left(\mathrm{mm} \mathrm{a}^{-1}\right)$ & 384 & 505 & 528 & 531 & 531 & 817 & 817 \\
\hline Sdep (keq ha-1 $\left.a^{-1}\right)$ & 1.2 & 4 & 0.47 & 0.47 & 0.47 & 0.47 & 0.47 \\
\hline Ndep (keq ha $\left.{ }^{-1} a^{-1}\right)$ & 0.26 & 1.4 & 0.55 & 0.35 & 1.06 & 0.35 & 1.06 \\
\hline \multicolumn{8}{|c|}{ W.I.E. Kahlenberg moder pine forests (Ebc-4n-c2) } \\
\hline $\mathrm{T}\left({ }^{\circ} \mathrm{C}\right)$ & 8.1 & 8.3 & 10.3 & 10.1 & 10.1 & 11.7 & 11.7 \\
\hline $\mathrm{PS}\left(\mathrm{mm} \mathrm{a}^{-1}\right)$ & 337 & 450 & 437 & 449 & 449 & 302 & 302 \\
\hline Sdep (keq ha $\left.{ }^{-1} a^{-1}\right)$ & 1.2 & 4 & 0.5 & 0.47 & 0.47 & 0.47 & 0.47 \\
\hline Ndep (keq ha $\left.{ }^{-1} a^{-1}\right)$ & 0.26 & 1.6 & 0.57 & 0.35 & 1.06 & 0.35 & 1.06 \\
\hline \multicolumn{8}{|c|}{ W.I.E. Peitz sub-continental mor humus pine forests (Ed-3n-b1) } \\
\hline $\mathrm{T}\left({ }^{\circ} \mathrm{C}\right)$ & 8.6 & 8.5 & 9.9 & 10.4 & 10.4 & 12.1 & 12.1 \\
\hline $\mathrm{PS}\left(\mathrm{mm} \mathrm{a}^{-1}\right)$ & 189 & 262 & 335 & 235 & 235 & 269 & 269 \\
\hline Sdep (keq ha $\left.{ }^{-1} a^{-1}\right)$ & 1.9 & 4.3 & 0.5 & 0.48 & 0.48 & 0.48 & 0.48 \\
\hline Ndep (keq ha $\left.{ }^{-1} a^{-1}\right)$ & 0.29 & 1.5 & 0.59 & 0.36 & 1.06 & 0.36 & 1.06 \\
\hline
\end{tabular}

to 2009 , the $\mathrm{S}$ deposition decreased to $0.3 \mathrm{keq} \mathrm{S} \mathrm{ha}{ }^{-1} \mathrm{a}^{-1}$, while the atmospheric $\mathrm{N}$ deposition decreased to only $1.1 \mathrm{keq} \mathrm{N} \mathrm{ha}^{-1} \mathrm{a}^{-1}$. In this period, the $\mathrm{pH}$ value rose again to 6.6. Base saturation continued to decline slightly and amounts to $93 \%$ in 2010 , due to the significant increase in ammonia deposition, as ammonia has a particularly high acidification potential compared to NOx. The $\mathrm{C} / \mathrm{N}$ ratio also continues to decrease to 12.6 , which was still within the reference range for the current mull humus class.

From 2010 to 2070, the temperature will rise from about $8.3^{\circ} \mathrm{C}$ to approximately $9.3^{\circ} \mathrm{C}$ in the RCP2.6 scenario and to about $12.8^{\circ} \mathrm{C}$ in the $\mathrm{RCP} 8.5$ scenario. The leachate rate will increase slightly in the RCP2.6 scenario but decrease significantly in the RCP8.5 scenario. The S deposition will be maintained at the 2009 level. The $5 \mathrm{~kg} \mathrm{~N}$ deposition scenario leads from 2010 to a reduction below Status' by 1920 ( $\left.0.34 \mathrm{keq} \mathrm{N} \mathrm{ha}^{-1} \mathrm{a}^{-1}\right)$. The $15 \mathrm{~kg} \mathrm{~N}$ deposition scenario simulates a very low NOx deposition at the 1920 level of $0.4 \mathrm{keq} \mathrm{Nha}^{-1} \mathrm{a}^{-1}$, but for the $\mathrm{NH} 3$ deposition a consistently high deposition of $0.7 \mathrm{keq} \mathrm{N} \mathrm{ha}^{-1} \mathrm{a}^{-1}$ since 1980. An influence of the various climate scenarios on the model results from 2010 was hardly discernible. The
C content will continue to decrease after 2010, presumably driven by the rising temperature in both scenarios, so that the activity of decomposing soil organisms will be stimulated. However, the decrease in C stock 2070 was more significant in the RCP2.6 scenario than in the RCP8.5 scenario $\left(\Delta C=120 \mathrm{~g} \mathrm{~m}^{-2}\right)$, presumably due to the more humid conditions that promote $C$ respiration.

In 2070, the $15 \mathrm{~kg} \mathrm{~N}$ deposition scenario causes a higher $\mathrm{N}$ pool than the $5 \mathrm{~kg} \mathrm{~N}$ deposition scenario $\left(\Delta \mathrm{N}=140 \mathrm{~g} \mathrm{~m}^{-2}\right)$ and at the same time a decrease in the $\mathrm{C} / \mathrm{N}$ ratio from 12.6 to 11 , which was still within the typical range of the current humus class mull. Under the $5 \mathrm{~kg} \mathrm{~N}$ deposition scenario, the $\mathrm{C} / \mathrm{N}$ ratio does not decrease further. Under both scenarios, $\mathrm{pH}$ and base saturation will remain at 2010 levels. Presumably, a new equilibrium will be achieved with this $\mathrm{C}: \mathrm{N}:(\mathrm{Ca}+\mathrm{Mg}+\mathrm{K})$ ratio.

The results of the dynamic modelling of the calciferous mull beech forests between 1920 and 2070 show plausible results depending on the related scenarios.

From the time series of the soil chemical and climate-ecological parameters the natural conditions for 
Table 2 Results of modelling soil processes at 15 sites in Germany for exemplary years

\begin{tabular}{|c|c|c|c|c|c|c|c|}
\hline & 1920 & 1985 & 2009 & $\begin{array}{l}2070 \\
\text { RCP2.6_5 kg N }\end{array}$ & $\begin{array}{l}2070 \\
\text { RCP2.6_15 kg N }\end{array}$ & $\begin{array}{l}2070 \\
\text { RCP8.5_5 kg N }\end{array}$ & $\begin{array}{l}2070 \\
\text { RCP8.5_15 kg N }\end{array}$ \\
\hline \multicolumn{8}{|c|}{ ICP Forests LII-606 calciphilous mull beech forests (Eb-5n-E2) } \\
\hline Base saturation (\%) & 99 & 95 & 93 & 93 & 93 & 93 & 93 \\
\hline $\mathrm{pH}\left(\mathrm{H}_{2} \mathrm{O}\right)(-)$ & 7.1 & 6.4 & 6.6 & 6.6 & 6.6 & 6.6 & 6.6 \\
\hline $\mathrm{C} / \mathrm{N}(-)$ & 18.5 & 14.6 & 12.6 & 12.6 & 11 & 12.6 & 11 \\
\hline \multicolumn{8}{|c|}{ ICP Forests LII-608 moder beech forests of the montane level (D1-5n-C2) } \\
\hline Base saturation (\%) & 38 & 25 & 20 & 21 & 21 & 21 & 21 \\
\hline $\mathrm{pH}\left(\mathrm{H}_{2} \mathrm{O}\right)(-)$ & 4.9 & 4.6 & 4.7 & 4.9 & 4.9 & 4.9 & 4.9 \\
\hline $\mathrm{C} / \mathrm{N}(-)$ & 19.7 & 13.7 & 13 & 10.2 & 9.9 & 10.2 & 9.5 \\
\hline \multicolumn{8}{|c|}{ ICP Forests LII-911 moder beech forests with fir of the montane level (C1-6d-B2) } \\
\hline Base saturation (\%) & 25 & 10.2 & 10 & 4 & 4 & 4 & 4 \\
\hline $\mathrm{pH}\left(\mathrm{H}_{2} \mathrm{O}\right)(-)$ & 5.1 & 4.3 & 4.7 & 4.4 & 4 & 4.4 & 4 \\
\hline $\mathrm{C} / \mathrm{N}(-)$ & 26 & 18 & 17 & 10.6 & 10.3 & 10.6 & 10.3 \\
\hline \multicolumn{8}{|c|}{ ICP Forests LII-1202 mor humus pine forests (Ebc- $4 n-c 1$ ) } \\
\hline Base saturation (\%) & 41 & 24 & 20 & 12 & 4 & 12 & 4 \\
\hline $\mathrm{pH}\left(\mathrm{H}_{2} \mathrm{O}\right)(-)$ & 5.2 & 4.5 & 4.6 & 4.5 & 3.9 & 4.5 & 3.9 \\
\hline $\mathrm{C} / \mathrm{N}(-)$ & 32 & 25 & 15.6 & 10.7 & 10.7 & 10.7 & 10.7 \\
\hline \multicolumn{8}{|c|}{ ICP IM Neuglobsow mor humus beech forests with pine (Eb-4n-B2) } \\
\hline Base saturation (\%) & 66 & 48 & 43 & 36 & 36 & 36 & 36 \\
\hline $\mathrm{pH}\left(\mathrm{H}_{2} \mathrm{O}\right)(-)$ & 5.6 & 5 & 5.5 & 5.4 & 5.4 & 5.4 & 5.4 \\
\hline $\mathrm{C} / \mathrm{N}(-)$ & 26.5 & 21 & 19.6 & 17.6 & 16.7 & 17.6 & 16.7 \\
\hline \multicolumn{8}{|c|}{ BÜK 33_61_31 moder pine forests (Eb-4n-C2) } \\
\hline Base saturation (\%) & 38 & 19 & 9 & 4 & 3 & 4 & 3 \\
\hline $\mathrm{pH}\left(\mathrm{H}_{2} \mathrm{O}\right)(-)$ & 4.9 & 4.4 & 4 & 3.8 & 3.8 & 3.8 & 3.8 \\
\hline $\mathrm{C} / \mathrm{N}(-)$ & 24 & 15.6 & 13 & 10 & 10 & 10 & 10 \\
\hline \multicolumn{8}{|c|}{ BÜK 34_42_31 moder hornbeam forests with small-leaved lime (Eb-5n-D1) } \\
\hline Base saturation (\%) & 60 & 54 & 52 & 50 & 50 & 50 & 50 \\
\hline $\mathrm{pH}\left(\mathrm{H}_{2} \mathrm{O}\right)(-)$ & 4.8 & 4.5 & 4.7 & 5 & 5 & 5 & 5 \\
\hline $\mathrm{C} / \mathrm{N}(-)$ & 22 & 13 & 11.1 & 9.1 & 8.5 & 9.1 & 8.5 \\
\hline \multicolumn{8}{|c|}{ BÜK 35_19_31 loamy mull beech forests (Ed-4n-C2) } \\
\hline Base saturation (\%) & 60 & 65 & 66 & 70 & 70 & 70 & 70 \\
\hline $\mathrm{pH}\left(\mathrm{H}_{2} \mathrm{O}\right)(-)$ & 5.2 & 5.2 & 5.4 & 5.7 & 5.7 & 5.7 & 5.7 \\
\hline $\mathrm{C} / \mathrm{N}(-)$ & 20 & 13 & 11.4 & 10.2 & 9.2 & 10.2 & 9.2 \\
\hline \multicolumn{8}{|c|}{ ICP Forests Level II 1405 mor humus pine forests (Eb-4n-b1) } \\
\hline Base saturation (\%) & 12 & 10 & 9.8 & 11 & 7.6 & 9.2 & 7 \\
\hline $\mathrm{pH}\left(\mathrm{H}_{2} \mathrm{O}\right)(-)$ & 4.33 & 4 & 4.5 & 4.6 & 4.2 & 4.4 & 4.2 \\
\hline $\mathrm{C} / \mathrm{N}(-)$ & 40 & 20 & 16.2 & 10.8 & 10.7 & 10.26 & 10.26 \\
\hline \multicolumn{8}{|c|}{ ICP Forests Level II 1602 moder beech forests with spruce and fir of the altimontane level (C3-6d-C2) } \\
\hline Base saturation (\%) & 18 & 13.6 & 12.8 & 13.8 & 13.8 & 13.8 & 13.8 \\
\hline $\mathrm{pH}\left(\mathrm{H}_{2} \mathrm{O}\right)(-)$ & 4.83 & 4.37 & 5.07 & 5.1 & 5.1 & 5.1 & 4.9 \\
\hline $\mathrm{C} / \mathrm{N}(-)$ & 31 & 22.5 & 19.9 & 15.5 & 14.5 & 14.1 & 13.2 \\
\hline \multicolumn{8}{|c|}{ ICP Forests Level II 1605 mor humus spruce forests of the altimontane level (C4-6d-B1) } \\
\hline Base saturation (\%) & 16 & 5.9 & 5 & 18.9 & 3.6 & 5.1 & 3 \\
\hline $\mathrm{pH}\left(\mathrm{H}_{2} \mathrm{O}\right)(-)$ & 5.1 & 4.4 & 5 & 5.4 & 4.3 & 4.4 & 4.1 \\
\hline $\mathrm{C} / \mathrm{N}(-)$ & 29 & 18.6 & 16.3 & 12.3 & 12 & 11.4 & 11.4 \\
\hline \multicolumn{8}{|c|}{ ICP Forests Level II 1609 moder spruce forests of the montane level (Dg-5n-c2) } \\
\hline Base saturation (\%) & 17 & 4.5 & 3.1 & 5 & 6.3 & 6.4 & 6.4 \\
\hline $\mathrm{pH}\left(\mathrm{H}_{2} \mathrm{O}\right)(-)$ & 5 & 4 & 4.7 & 4.8 & 4.9 & 4.9 & 4.9 \\
\hline $\mathrm{C} / \mathrm{N}(-)$ & 31 & 22 & 18.9 & 15 & 13.7 & 13.9 & 12.6 \\
\hline
\end{tabular}


Table 2 (continued)

\begin{tabular}{|c|c|c|c|c|c|c|c|}
\hline & 1920 & 1985 & 2009 & $\begin{array}{l}2070 \\
\text { RCP2.6_5 kg N }\end{array}$ & $\begin{array}{l}2070 \\
\text { RCP2.6_15 kg N }\end{array}$ & $\begin{array}{l}2070 \\
\text { RCP8.5_5 kg N }\end{array}$ & $\begin{array}{l}2070 \\
\text { RCP8.5_15 kg N }\end{array}$ \\
\hline \multicolumn{8}{|c|}{ W.I.E. Biesenthal moder beech forests with sessile oak (Eb-4n-C1) } \\
\hline Base saturation (\%) & 38.7 & 3 & 3 & 3 & 3 & 3 & 2 \\
\hline $\mathrm{pH}\left(\mathrm{H}_{2} \mathrm{O}\right)(-)$ & 5.2 & 3.7 & 4.6 & 4.7 & 4.4 & 4.7 & 4.4 \\
\hline $\mathrm{C} / \mathrm{N}(-)$ & 32.6 & 18.8 & 14 & 10.6 & 8.3 & 9.2 & 8.2 \\
\hline \multicolumn{8}{|c|}{ W.I.E. Kahlenberg moder pine forests (Ebc-4n-c2) } \\
\hline Base saturation (\%) & 20 & 11 & 11 & 21 & 16 & 21 & 15 \\
\hline $\mathrm{pH}\left(\mathrm{H}_{2} \mathrm{O}\right)(-)$ & 4.8 & 4.2 & 4.9 & 5.2 & 4.8 & 5 & 4.7 \\
\hline $\mathrm{C} / \mathrm{N}(-)$ & 35.6 & 18.8 & 15 & 10.2 & 10.1 & 9.6 & 9.5 \\
\hline \multicolumn{8}{|c|}{ W.I.E. Peitz sub-continental mor humus pine forests (Ed-3n-b1) } \\
\hline Base saturation (\%) & 12 & 10 & 9.8 & 11 & 10.3 & 11 & 10.1 \\
\hline $\mathrm{pH}\left(\mathrm{H}_{2} \mathrm{O}\right)(-)$ & 4.3 & 4 & 4.5 & 4.6 & 4.3 & 4.6 & 4.4 \\
\hline $\mathrm{C} / \mathrm{N}(-)$ & 39.5 & 20.1 & 16.2 & 10.8 & 10.8 & 10.3 & 10.3 \\
\hline
\end{tabular}

the potential forest ecosystem type (pEsT), for the current forest ecosystem type (cEsT) and for the modelled development until 2070 result as follows:

1. pEsT: calciferous mull beech forests

2. cEsT: calciferous mull beech forests

3. Future possible ecosystem types according to scenario RCP2.6_5 kg: calciferous mull beech forests

4. Future possible ecosystem types according to scenario RCP2.6_15 kg: calciferous mull beech forests

5. Future possible ecosystem types according to scenario RCP8.5_5 kg: calciferous mull beech forests

6. Future possible ecosystem types according to scenario RCP8.5_15 kg: calciferous mull beech forests.

\section{Relevance of modelling results for the projection of possible future ecosystem conditions and for related forest management options}

The dynamic modelling of soil properties exposed to atmospheric $\mathrm{N}$ deposition and climate change at 15 selected sites of different ecosystem types aimed at identifying potential developments of ecosystem conditions up to a possible change of the current ecosystem type.

The VSD-model only takes into account soil chemical changes. The resulting changes in tree vitality, selfregeneration potential and the necessary adjustments in management are only the result of the interpretation and evaluation of the model results, as exemplified by the 15 forest sites considered in following chapters.

\section{ICP Forests Level II Site 606}

For the period up to 2070, the results do not indicate any threat to the ecosystem (see "Results exemplified by ICP Forests Level II Site 606" section).

The ecosystem type will retain under the conditions of expected climate change and slightly increased $\mathrm{N}$ deposition. This is due to the high buffer capacity, good nutrient and water supply, and overall the high resilience of the site and the vegetation within it. The heat gain of the site in connection with an adequate water supply and an optimal nutrient supply will with high probability lead to an increase of the net primary production of tree wood depending on the characteristics of the modelled site change. The natural accompanying tree species of copper beech such as mountain maple, ash, mountain elm and Norway maple should be supported by forestry measures. This will further increase plant species diversity and the adaptability of the ecosystem to changing environmental conditions.

The future possible ecosystem type according to scenario RCP2.6_5 $\mathrm{kg}$ is a calciferous mull beech forests, according to scenario RCP2.6_15 kg: calciferous mull beech forests, according to scenario RCP8.5_5 kg: calciferous mull beech forests and according to scenario RCP8.5_15 kg: calciferous mull beech forests. 


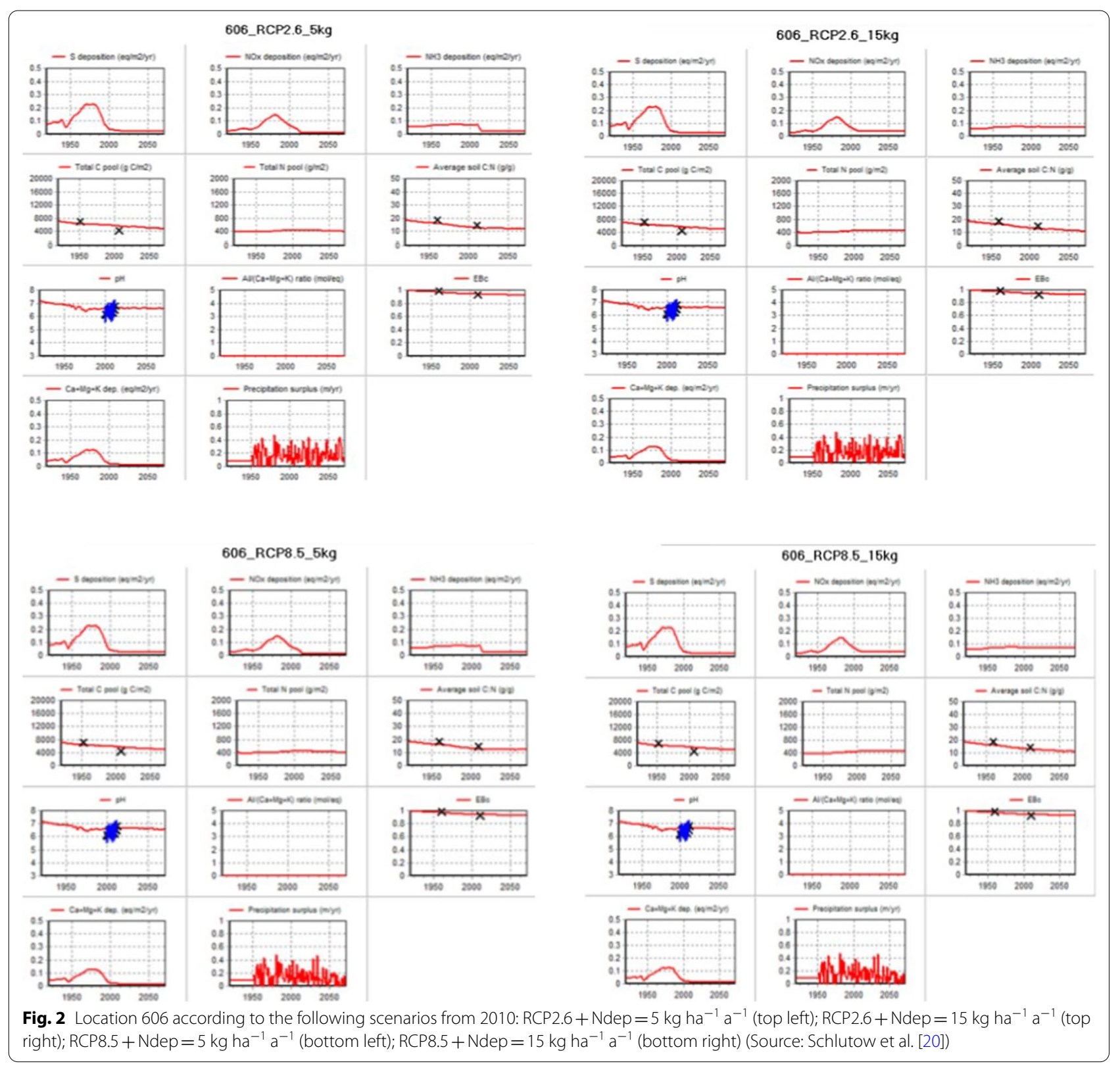

\section{ICP Forests Level II Site 608}

The results of the dynamic modelling of the moder beech forests of the montane level already show a clear change in the ecosystem status for the simulation period between 1920 and 2009, which, depending on the related scenarios, continues until 2070 and leads to a change in the ecosystem type. On the one hand, between 1985 and 2009 the mean air temperature was increased by $1.4 \mathrm{~K}$ and the mean precipitation decreased by $16 \%$. On the other hand, already between 1920 and 1985 there was a narrowing of the $\mathrm{C} / \mathrm{N}$ ratio combined with a reduction of the base saturation and the $\mathrm{pH}$ value.

In both assumed deposition scenarios, the $\mathrm{C} / \mathrm{N}$ ratio was further narrowed by the $\mathrm{N}$ deposition until 2070. The buffer potential of the basic volcanic rock leads to the formation of harmonious humus states, so that in the case of deposition of up to $15 \mathrm{~kg}$ per hectare and year a new type of material cycle was formed, which was associated with the formation of the humus class clay brown dust. The eutrophication of the site thus does not lead to any adverse impact on forest nutrition. 
Table 3 Structure of description of the modelling results

\begin{tabular}{|c|c|c|c|c|c|}
\hline \multicolumn{3}{|l|}{ RCP 2.6_5 kg N_dep } & \multicolumn{3}{|l|}{ RCP 2.6_15 kg N_dep } \\
\hline $\begin{array}{l}\text { S deposition } \\
\left({\left.\text { eq } \mathrm{m}^{-2} \mathrm{a}^{-1}\right)}\right.\end{array}$ & $\begin{array}{l}\text { NOx deposition } \\
\left(\text { eq } \mathrm{m}^{-2} \mathrm{a}^{-1}\right)\end{array}$ & $\begin{array}{l}\mathrm{NH}_{3} \text { deposition } \\
\left(\text { eq } \mathrm{m}^{-2} \mathrm{a}^{-1}\right)\end{array}$ & $\begin{array}{l}\text { S deposition } \\
\quad\left(\text { eq } \mathrm{m}^{-2} \mathrm{a}^{-1}\right)\end{array}$ & $\begin{array}{l}\text { NOx deposition } \\
\left(\text { eq } \mathrm{m}^{-2} \mathrm{a}^{-1}\right)\end{array}$ & $\begin{array}{l}\mathrm{NH}_{3} \text { deposition } \\
\left(\text { eq } \mathrm{m}^{-2} \mathrm{a}^{-1}\right)\end{array}$ \\
\hline Total C pool $\left(\mathrm{g} \mathrm{C} \mathrm{m}^{-2}\right)$ & Total N pool $\left(\mathrm{g} \mathrm{N} \mathrm{m}^{-2}\right)$ & Average soil C:N $\left(\mathrm{g} \mathrm{g}^{-1}\right)$ & Total C pool $\left(\mathrm{g} \mathrm{C} \mathrm{m}^{-2}\right)$ & Total N pool $\left(\mathrm{g} \mathrm{N} \mathrm{m}^{-2}\right)$ & Average soil C:N $\left(\mathrm{g} \mathrm{g}^{-1}\right)$ \\
\hline $\mathrm{pH}$ & $\begin{array}{l}\mathrm{Al} /(\mathrm{Ca}+\mathrm{Mg}+\mathrm{K}) \\
\quad\left(\mathrm{mmoleq} \mathrm{eq}^{-1}\right)\end{array}$ & $\mathrm{EBC}$ & $\mathrm{pH}$ & $\begin{array}{l}\mathrm{Al} /(\mathrm{Ca}+\mathrm{Mg}+\mathrm{K}) \\
(\mathrm{mmol} \mathrm{eq} \\
\end{array}$ & $\mathrm{EBC}$ \\
\hline 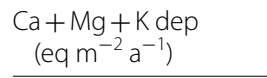 & $\begin{array}{l}\text { PS precipitation surplus } \\
\left(\mathrm{m} \mathrm{a}^{-1}\right)\end{array}$ & & 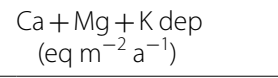 & $\begin{array}{l}\text { PS precipitation surplus } \\
\left(\mathrm{m} \mathrm{a}^{-1}\right)\end{array}$ & \\
\hline \multicolumn{3}{|l|}{ RCP 8.5_5 kg N_dep } & \multicolumn{3}{|l|}{ RCP 8.5_15 kg N_dep } \\
\hline $\begin{array}{l}\text { S deposition } \\
\left(\text { eq } \mathrm{m}^{-2} \mathrm{a}^{-1}\right)\end{array}$ & $\begin{array}{l}\text { NOx deposition } \\
\left(\text { eq } \mathrm{m}^{-2} \mathrm{a}^{-1}\right)\end{array}$ & $\begin{array}{l}\mathrm{NH}_{3} \text { deposition } \\
\left(\text { eq } \mathrm{m}^{-2} \mathrm{a}^{-1}\right)\end{array}$ & $\begin{array}{l}\text { S deposition } \\
\left(\text { eq } \mathrm{m}^{-2} \mathrm{a}^{-1}\right)\end{array}$ & $\begin{array}{l}\text { NOx deposition } \\
\left(\text { eq } \mathrm{m}^{-2} \mathrm{a}^{-1}\right)\end{array}$ & $\begin{array}{l}\mathrm{NH}_{3} \text { deposition } \\
\left(\text { eq } \mathrm{m}^{-2} \mathrm{a}^{-1}\right)\end{array}$ \\
\hline Total C pool $\left(\mathrm{g} \mathrm{C} \mathrm{m}^{-2}\right)$ & Total N pool $\left(\mathrm{g} \mathrm{N} \mathrm{m}^{-2}\right)$ & Average soil C:N $\left(\mathrm{g} \mathrm{g}^{-1}\right)$ & Total C pool $\left(\mathrm{g} \mathrm{C} \mathrm{m}^{-2}\right)$ & Total N pool $\left(\mathrm{g} \mathrm{N} \mathrm{m}^{-2}\right)$ & Average soil C:N $\left(\mathrm{g} \mathrm{g}^{-1}\right)$ \\
\hline $\mathrm{pH}$ & $\begin{array}{l}\mathrm{Al} /(\mathrm{Ca}+\mathrm{Mg}+\mathrm{K}) \\
\left.(\mathrm{mmoleq})^{-1}\right)\end{array}$ & $\mathrm{EBC}$ & $\mathrm{pH}$ & $\begin{array}{l}\mathrm{Al} /(\mathrm{Ca}+\mathrm{Mg}+\mathrm{K}) \\
\quad\left(\mathrm{mmoleq} \mathrm{eq}^{-1}\right)\end{array}$ & $\mathrm{EBC}$ \\
\hline 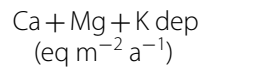 & $\begin{array}{l}\text { PS precipitation surplus } \\
\left(\mathrm{m} \mathrm{a}^{-1}\right)\end{array}$ & & $\begin{array}{c}\mathrm{Ca}+\mathrm{Mg}+\mathrm{Kdep} \\
\left(\mathrm{eq} \mathrm{m}^{-2} \mathrm{a}^{-1}\right)\end{array}$ & $\begin{array}{l}\text { PS precipitation surplus } \\
\left(\mathrm{m} \mathrm{a}^{-1}\right)\end{array}$ & \\
\hline
\end{tabular}

The climatic change leads to significant changes in the heat and water balance of the ecosystem, which lead to a shift in competition in favour of the native oak species, in conjunction with increased $\mathrm{N}$ deposition of up to $15 \mathrm{~kg}$ per hectare and year in favour of hornbeam, small-leaved lime and mountain maple. The possible future ecosystem types identified were therefore the moder beech forests with sessile oak and, in the case of long-term elevated $\mathrm{N}$ deposition, the loamy brown mull beech forests with small-leaved lime.

Climate change leads to a loss of the typical mountain forest character and thus to a changed identity of the ecosystem. Plant species diversity both in the tree layer and in the ground vegetation was expected to increase due to climatic change in connection with $\mathrm{N}$ deposition. Net primary production of tree wood will decrease due to lower rainfall availability, although this decrease can only be partially offset by an improvement in nutrient supply due to increased $\mathrm{N}$ deposition. The stability of the tree population was not expected to be endangered. A meaningful forestry support of the transformation process consists in the promotion of the accompanying tree species of the beech and thus the mixed forest character.

The future possible ecosystem type according to scenario RCP2.6_5 kg could be the moder beech forests of the montane level with disharmonic ratio of $\mathrm{C} / \mathrm{N}$ and base saturation, according to scenario RCP2.6_15 kg: moder beech forests of the montane level with disharmonic ratio of $\mathrm{C} / \mathrm{N}$ and base saturation, according to scenario RCP8.5_5 kg: moder beech forests with sessile oak with sessile oak with disharmonic ratio of $\mathrm{C} / \mathrm{N}$ and base saturation and according to scenario RCP8.5_15 kg: loamy brown mull beech forests with small-leaved lime with disharmonic ratio of $\mathrm{C} / \mathrm{N}$ and base saturation.

\section{ICP Forests Level II Site 911}

The results of the dynamic modelling of the moder beech forests with fir of the montane level show a significant decrease in base saturation with a simultaneous significant narrowing of the C/N ratio between 2009 and 2070, while the state between 1985 and 2009 remains largely unchanged. This trend was independent of the amount of N quantity registered between 2009 and 2070. Since climate change in the period 2041-2070 leads to a significant reduction of the leachate discharge, an accumulation of $\mathrm{N}$ in the ecosystem triggered by this could be responsible for the simulated trend.

The significant increase in the mean air temperature leads to a reduction in the proportion of conifers and a segregation of the fir-beech forest, so that a moder beech forests of the montane level was to be expected as a probable future ecosystem type.

Other possible options for future ecosystem types that emerge from the VSD+ results include according to scenario RCP2.6_5 kg a moder beech forests of the montane level with disharmonic ratio of $\mathrm{C} / \mathrm{N}$ and base saturation, according to scenario RCP2.6_15 kg a moder beech forests of the montane level with disharmonic ratio of $\mathrm{C} / \mathrm{N}$ and base saturation, according to scenario RCP8.5_5 kg a moder beech forests of the montane level with disharmonic ratio of $\mathrm{C} / \mathrm{N}$ and base saturation and according to scenario RCP8.5_15 kg the moder beech forests of the montane level with disharmonic ratio of $\mathrm{C} / \mathrm{N}$ and base saturation. 


\section{ICP Forests Level II Site 1202}

The results of the dynamic modelling show a steadily increasing narrowing of the $\mathrm{C} / \mathrm{N}$ ratio from 1920 to 2070, which covers the entire ecological range from 32 to 10.7 . This narrowing can initially be interpreted as a consequence of natural site degradation of the pine forest, but increasingly as a consequence of anthropogenic $\mathrm{N}$ deposition. In the case of increased atmospheric $\mathrm{N}$ deposition of up to $15 \mathrm{~kg}$ per hectare and year, a further reduction in base saturation and $\mathrm{pH}$ value as a result of $\mathrm{N}$-eutrophication occurs by 2070 , as well as the formation of disharmonious humus conditions, which are associated with disturbed nutritional conditions of the pine tree species and are highly likely to lead to an increased mortality rate and a possible death of the pine stand.

As a silvicultural sensible countermeasure, the conversion into a tree population corresponding to the expected potentially natural ecosystem type must be accompanied by timely control. For this purpose, naturally arriving deciduous tree undergrowth must be consistently promoted. In the case of the RCP 2.6 scenario, the future possible ecosystem type to be assumed was a moder beech forests with sessile oak, in the case of the RCP 8.5 scenario a moder sessile oak forests.

The following possible future ecosystems are also derived from the VSD+ findings: according to scenario RCP2.6_5 kg: mor humus beech forests with pine with disharmonic ratio of $\mathrm{C} / \mathrm{N}$ and base saturation, according to scenario RCP2.6_15 kg: mor humus beech forests with pine with disharmonic ratio of $\mathrm{C} / \mathrm{N}$ and base saturation according to scenario RCP8.5_5 kg: mor humus pine grape oak forest, mor humus sessile oak forests with pine with disharmonic ratio of $\mathrm{C} / \mathrm{N}$ and base saturation, according to scenario RCP8.5_15 kg: sandy mor humus pine forests, sub-continental mor humus pine forests with disharmonic ratio of $\mathrm{C} / \mathrm{N}$ and base saturation.

\section{Intensive monitoring site Neuglobsow mixed forest}

The results of the dynamic modelling of the mor humus beech forests with pine show a steady narrowing of the $\mathrm{C} / \mathrm{N}$ ratio from 26.5 to 19.6 in 2009 since 1920, depending on the level of the expected $\mathrm{N}$ deposition the $\mathrm{C} / \mathrm{N}$ ratio decreases further to 17.6 or 16.7 in 2070. Increased $\mathrm{N}$ deposition since the middle of the last century can be assumed to be the main cause of this obvious $\mathrm{N}$-eutrophication. Presumably, this population developed out of a pine afforestation and the good supply of basic cations naturally given on the late Pleistocene site, in connection with the ameliorative effect of the ingrowing beech, guarantees a balanced nutrient supply. An improvement of the humus condition from mor humus towards moder conditions was therefore very likely.
In the case of the moderate climate scenario $\mathrm{RCP}$ 2.6 , the proportion of beech will probably continue to increase at the expense of pine until 2070. The water balance situation, which will be worsening as a result of increasing air temperatures, could, however, lead to a situation in which native oak species gain a considerable share of the total, especially by rejuvenating larger gaps in the population which can no longer be closed by the beech. A development towards the moder beech forests with sessile oak thus presents itself as a probable scenario of ecosystem development. The climate scenario RCP 8.5 would aggravate the water balance situation to such an extent that the beech would clearly lose its competitive power and a moder sessile oak forests would develop. The plasticity of the stand can be increased by consistently promoting naturally developing parts of deciduous trees.

Other possible options for future ecosystem types that emerge from the VSD+ results include according to scenario RCP2.6_5 kg a sandy moder beech forests, according to scenario RCP2.6_15 kg: sandy mull beech forests, according to scenario RCP8.5_5 kg: moder beech forests with sessile oak or moder sessile oak forests with pine (Ed-3n-C2) and according to scenario RCP8.5_15 kg: sandy mull beech forests.

\section{BÜK1000N reference area 336131}

The development of the moder pine forests was characterised by the acidifying effect of atmospheric deposition, in particular $\mathrm{N}$, in combination with a base-poor source rock. This manifests itself in a strong narrowing of the $\mathrm{C} / \mathrm{N}$ ratio and an extreme decrease of the base saturation with a simultaneous significant increase of the total evaporation until 2070 due to increasing temperatures.

The results of the dynamic modelling lead to the interpretation that the stability of the moder pine forest was no longer guaranteed as a result of this site development and that in the long term the potential natural ecosystem types to be expected according to the respective climate scenarios RCP 2.6 and RCP 8.5, i.e. a moder beech forests with sessile oak or a moder hornbeam forests with smallleaved lime, could develop. It would be advisable to artificially rejuvenate the stock through appropriate forestry measures, such as pre-cultivation of the sessile oak, and to transfer it to the potential natural ecosystem type.

The following possible future ecosystem types can also be derived from the VSD+ modelling result: scenario RCP2.6_5 kg: moder pine forests with disharmonic ratio of $\mathrm{C} / \mathrm{N}$ and base saturation, scenario $\mathrm{RCP} 2.6 \_15 \mathrm{~kg}$ : sandy moder beech forests with disharmonic ratio of $\mathrm{C} / \mathrm{N}$ and base saturation, scenario RCP8.5_5 kg: mor humus sessile oak forests with disharmonic ratio of $\mathrm{C} / \mathrm{N}$ and base saturation and according to scenario RCP8.5_15 kg: 
moder beech forests with sessile oak with disharmonious ratio of $\mathrm{C} / \mathrm{N}$ and base saturation.

\section{BÜK1000N reference area 344231}

The Loamy mull beech forests in the Saxon-Thuringian loess hill country possesses sufficient ecological plasticity to adapt to the changing climatic conditions with moderate to increased $\mathrm{N}$ deposition in accordance with the given scenarios due to the given soil conditions and a stocking corresponding to the potential natural vegetation. The moderate increase in mean air temperature expected by 2070 with comparable annual precipitation, but with a different seasonal distribution, leads to a weakening of the competitive power of the beech-red, which was why the formation of a loamy brown mull beech forests with small-leaved lime was probable in both climate scenarios. In the case of scenario RCP 8.5, an extreme increase in summer dryness could lead to the formation of a Brown mull hornbeam forests with small-leaved lime without significant participation of beech.

The climatically induced change of the natural tree species composition was expected to be accompanied by the promotion of naturally arriving accompanying tree species of the beech such as hornbeam, small-leaved lime, sycamore maple or wild cherry.

\section{BÜK1000N reference area 351931}

Due to its current tree species composition (pedunculate oak, hornbeam, small-leaved lime), the wood of the moder hornbeam forests with small-leaved lime has a high plasticity for adaptation to the assumed increase in mean air temperature with a simultaneous increase in summer dryness and increased $\mathrm{N}$ deposition.

No special forestry measures are required to increase adaptability; possible accompanying forestry measures should be aimed at increasing valuable timber production.

Therefore, the future possible ecosystem types according to scenario A1B_5 $\mathrm{kg}$ would be the mull hornbeam forests with small-leaved lime and the same according to scenario A1B_15 kg.

\section{ICP Forests Level II Site 1405}

The mor humus pine forests with a high representativeness for the Central European pine forests of the region South-Brandenburg/North-Saxony shows in the simulation until 2070 a continuation of the trend of a narrowing of the $\mathrm{C} / \mathrm{N}$ ratio with decreasing base saturation, which can be interpreted as a consequence of increased $\mathrm{N}$ deposition in connection with the base-poor source rock. In connection with this, the increase in the mean air temperature, which varies depending on the climate scenario, with slightly increasing (RCP 2.6) or decreasing
(RCP 8.5) annual precipitation leads to an increased risk to the stand due to nutrient disharmonies in connection with increased water stress, which favour the occurrence of pest calamities. The risk of forest fires was also significantly increased.

Within the fairway of the ecosystem type, a change between the vegetation type blueberry pine forest and the vegetation type wire-necked pine forest was to be expected. In order to reduce the risks, forest measures should be directed towards the initialisation and promotion of natural deciduous tree regeneration (indigenous oak species, sand birch, aspen, mountain ash) with the aim of transforming it into the potential natural ecosystem type of sandy moder beech forests.

Other possible options for future ecosystem types that emerge from the VSD+ results include according to scenario RCP2.6_5 kg a mor humus-moder pine forests with disharmonic ratio of $\mathrm{C} / \mathrm{N}$ and base saturation, according to scenario RCP8.5_5 kg: mor humus sessile oak forests with pine or mor humus sessile oak forests with disharmonic ratio of $\mathrm{C} / \mathrm{N}$ and base saturation and according to scenario RCP8.5_15 kg: sandy mor humus pine forests or sub-continental mor humus-moder pine forests with disharmonic ratio of $\mathrm{C} / \mathrm{N}$ and base saturation.

\section{ICP Forests Level II Site 1602}

The moder beech forests with spruce and fir of the altimontane level in the Vessertal Biosphere Reserve corresponds to the natural type of forest that forms in the ridges of the Thuringian Forest under today's climatic conditions in self-organisation. The increased $\mathrm{N}$ deposition that had taken place in the past and may be expected in the future leads to a narrowing of the $\mathrm{C} / \mathrm{N}$ ratio. In particular, the expected further increase in air temperature leads to a significant change in the vegetation composition, so that the typical high mountain forest character will be lost and, in the case of the RCP 2.6 scenario, the formation of a potential natural moder beech forests with fir of the montane level or a natural moder beech forests on bunter in the case of the RCP 8.5 scenario becomes probable in the self-organised development.

On the basis of this finding and depending on the targets for this site, it would be appropriate either to maintain the coniferous tree proportion by consistently exempting it from the pressing beech, which would imply an increasing forest-induced deviation from the newly developing forest nature as a result of climate change, or to permit the self-dynamic development towards a beech forest with a decreasing coniferous tree proportion. A balanced compromise from both a forestry and nature conservation point of view would be to accompany the development of the moder beech forests with fir of the 
montane level forest, i.e. to strive for the development and promotion of the fir share.

\section{ICP Forests Level II Site 1605}

The mor humus spruce forests of the altimontane level on the ridges of the Thuringian Forest will endangered by the expected increase of the mean air temperature in connection with increased $\mathrm{N}$ deposition in its current formation as a natural forest type which forms in selforganisation under the previous ecological conditions. There will be a clear change in the vegetation composition so that the typical high mountain forest character will be lost and the formation of a potential natural mor humus beech mountain forest was likely in the selforganised development.

On the basis of this finding and depending on the targets for this site, it would be appropriate either to maintain the spruce content by consistently exempting it from the pressing beech, which would lead to the formation of a mor humus spruce forests of the montane level while preserving the current stock picture, whereby the increasing deviation from the developing new forest nature was accepted. Alternatively, it was possible to permit the self-dynamic development towards a beech forest with decreasing spruce content in favour of the beech.

\section{ICP Forests Level II Site 1609}

This forestry-induced moder spruce forests of the montane level, which replaces a potential natural moder beech forests with fir of the montane level at this site, was characterised by the fact that the white fir has the predominant building value with a base area share of almost $60 \%$ compared to the spruce. The almost complete absence of the beech and the high proportion of spruce (40\%) determine the ecological assignment to the spruce mountain forest. The fir, which predominates in this population, was to a lesser extent also a component of the natural beech forest community and was to be evaluated positively from an ecological and nature conservation point of view. The almost complete absence of beech, however, leads to only a low correspondence with the spectrum of natural site tree species of less than one-third, which results in a rather low adaptability to expected environmental changes (in particular global warming).

The low base saturation of the topsoil could have a negative effect on the balanced nutrient availability in the case of the narrowing of the $\mathrm{C} / \mathrm{N}$ ratio in the topsoil expected in the scenarios. In terms of silviculture, it would therefore be advisable to promote the proportion of beech in order to increase adaptability to changing environmental conditions and to achieve an ameliorative effect on the condition of the topsoil.

The following possible future ecosystem types can be derived from the VSD+ modelling result: according to scenario RCP2.6_15 kg the Brown mull fir forests of the montane level or moder beech forests with fir of the montane level with disharmonic ratio of $\mathrm{C} / \mathrm{N}$ and base saturation, according to scenario RCP8.5_5 kg: sandy moder beech forests or moder spruce forests with disharmonic ratio of $\mathrm{C} / \mathrm{N}$ and base saturation, according to scenario RCP8.5_15 kg: loamy mull beech forests with disharmonic ratio of $\mathrm{C} / \mathrm{N}$ and base saturation.

\section{Site W.I.E. Biesenthal}

The sandy moder beech forest with sessile oak in the north-eastern lowlands of Germany corresponds to the current potential natural ecosystem type. The empirical findings from forest ecosystem research, which originate from photographs taken in 1993, 1997 and 2000 and were documented and interpreted by Jenssen et al. [8], confirm a high buffering capacity of the Young Pleistocene site despite elevated $\mathrm{N}$ deposition and the resulting slight narrowing of the $\mathrm{C} / \mathrm{N}$ ratio of the topsoil, which do not consistently correspond to the findings of dynamic modelling. Here, an extreme lowering of the base saturation was particularly noticeable, which seems to be less plausible under the conditions of the Young Pleistocene.

In the climate scenario RCP 2.6, the fairway of the current ecosystem type was not abandoned, while in the scenario RCP 8.5, due to the significant warming and the increase of summer drought, the formation of a Sandy moder beech forests was probable. This type change occurs as a result of the weakened competitiveness of the beech compared to the native oak species and the hornbeam.

An increase in the ecological plasticity of the beech stock can be achieved by taking care to consistently promote naturally arriving deciduous tree species, in particular hornbeam and native oak species, in the forthcoming natural regeneration and young stock maintenance. A mosaic-like structure of the different tree species should be aimed at in order to counteract early segregation of the beech stock.

\section{Site W.I.E. Kahlenberg}

This mor humus-moder pine forests in the Young Pleistocene northeast Brandenburg was under the influence of excessive $\mathrm{N}$ deposition in the windward catchment area of a pig fattening plant between 1975 and 1990. As a result of the very high $\mathrm{S}$ deposition, the $\mathrm{pH}$ dropped from 4.8 to 4.2 in the period from 1920 to 1985 and the base saturation from 20 to $11 \%$. The $\mathrm{N}$ deposition caused 
a decrease of the $\mathrm{C} / \mathrm{N}$ ratio in the period from 1920 to 1985 from 20 to 11 . Thus the $\mathrm{C} / \mathrm{N}$ value in 1985 was already below the reference span of the current humus class of mor humus-like moder (typical C/N: 17-26). An influence of the various climate scenarios on the model results from 2010 was clearly discernible for the $\mathrm{C} / \mathrm{N}$ ratio. While the $\mathrm{C} / \mathrm{N}$ ratio was $10.1-10.2$ according to the 2.6 climate scenario $\left(2070: 10.1{ }^{\circ} \mathrm{C}\right)$, it will fall to $9.5-9.6$ according to the 8.5 scenario $\left(2070: 11.7^{\circ} \mathrm{C}\right)$. The $\mathrm{C}$ content will continue to decline slightly after 2010 .

Both deposition scenarios result in a slightly increasing $\mathrm{N}$ pool in 2070 , a significantly decreasing $\mathrm{C}$ pool and thus a sharp drop in the $\mathrm{C} / \mathrm{N}$ ratio at the same time.

According to all scenarios, the current ecosystem type will continue to change increasingly disharmoniously, especially in the future because the $\mathrm{C} / \mathrm{N}$ ratio was too low for the site type. From the time series of soil chemical and climatic parameters, disharmonious soil properties result for the potential forest ecosystem type (pEsT), for the current forest ecosystem type (cEsT) and for the modelled development until 2070 according to all 4 scenarios, which do not allow any forest type to develop optimally.

In order to counteract a possible destabilisation of the pine stand, a pre-cultivation of deciduous trees and a forest-controlled conversion into the potential natural ecosystem type Mor humus Pine Oak Forest to be expected under climate change was recommended.

\section{Site W.I.E. Peitz}

The site was macroclimatically and pedologically representative for around $50 \%$ of the forest area of Brandenburg [8]. For centuries, the population was exposed to anthropogenic degradation through litter use, forest pasture and forest fires, which regularly destroyed the organic layer of humus. As a result of the degrading influences, a pine forest community rich in lichen emerged on the site. In the second half of the twentieth century, the ecosystem was exposed for many years to atmospheric deposition of $\mathrm{N}$ compounds in combination with basic fly ashes and S compounds. Under the influence of natural regradation and, in particular, the atmospheric deposition in the second half of the last century, the condition of the topsoil has continuously approached the natural site potential again. It may have been of major importance for this deposition-induced site degradation that, in addition to the deposition of $\mathrm{N}$ and $\mathrm{S}$ compounds, basic dusts were also introduced, so that nutrient disharmonies were at least partially compensated for or prevented. These empirical findings [8] were confirmed by the results of retrospective dynamic modelling. In the course of this development, the site has become convenient for deciduous forests again, so that the potential natural ecosystem type today was a mor humus sessile oak forests with pine.
The results of the dynamic modelling show a further narrowing of the $\mathrm{C} / \mathrm{N}$ ratio and a further tightening of the water balance. A sub-continental mor humus-moder pine forests can be assumed to be the future ecosystem type while maintaining current stocking. In order to further increase humus condition, productivity and above all stability of the stand (risk of forest fire!) in view of climate change, the proportion of deciduous trees, especially sessile oak, should be consistently developed and promoted. In the medium and long term, this forest management should lead to the development of the expected future potential natural ecosystem type of moder sessile oak forests with pine.

\section{Discussion}

The relevance of modelling results for potential future forest management options depends to a certain degree from the reliability interms of the uncertainty of the data used ("Uncertainties" section) and the sensitivity of modelling ("Sensitivity analysis" section).

\section{Uncertainties}

The uncertainties of the input data are hard to be quantified since a thorough research data management in terms of transparent documentation and archiving is still only a desideratum in Germany [21]. The uncertainties seem to be particularly high for the weathering rate of basic cations, since there were hardly any measurements available. Even the carbon stock at the beginning of the simulation can only be estimated without quantitative knowledge about the (un)certainty. The effects of the uncertainties on the resulting time series could largely be reduced by calibration using measurement data. Naturally, the uncertainties at the ICP Forests Level II and ICP IM sites could be better reduced than at the BÜK reference sites. The aim of the modelling of the BÜK reference areas, however, was not the site-specific mapping of the actual site parameters, but the derivation of the time series of the changing soil parameters typical for the BÜK unit with changing $\mathrm{N}$ deposition and climate parameters. In this respect, the uncertainties at the BÜK reference areas are more acceptable than at the ICP Forests Level II and ICP IM sites.

The model-internal uncertainties cannot be estimated by users. It can only be argued whether the results are plausible and correspond to experience. It was particularly noticeable that the $\mathrm{C} / \mathrm{N}$ ratio does not rise again at any research site if the $\mathrm{N}$ deposition in the $5 \mathrm{~kg}$ deposition scenario falls significantly below the 1920 level. However, this would be to be expected if the uptake of $\mathrm{N}$ by vegetation plus immobilisation and denitrification rates exceeded the $\mathrm{N}$ deposition. However, this was not 
provided for in the model and was displayed as an error if the input value for the $\mathrm{N}$ uptake rate in biomass was higher than the deposition. But such scenarios cannot be ruled out in the future. It was expected that the mineralisation rate will increase with rising temperatures and sufficient soil moisture and that the $\mathrm{N}$ supply will be reduced again by absorption into the biomass and leaching. However, climate change also reduces the $\mathrm{C}$ stock in the soil, while the $\mathrm{C}$ stock in the biomass increases, as the net primary production increases with increasing vegetation period length. How the $\mathrm{C} / \mathrm{N}$ ratio will develop under these forecasts can be seen by comparing the results of the first with the second soil condition survey. Grüneberg et al. [22] analysed these results and found rising $\mathrm{C} / \mathrm{N}$ ratios in the Germany-wide average over the period 1996-2008. The relationships would have to be investigated and implemented accordingly in the next model versions of VSD+.

Questions about plausibility are also raised by the resulting time series from VSD+ modelling that at each study site the carbon content in the top soil is continuously decreasing. This seems particularly unlikely at sites that have meanwhile entered the aluminium buffer due to very high acidification deposition, where both the base deficiency and the toxic effect of aluminium must have led to an inhibition of the humus destruents. Furthermore, $\mathrm{pH}$ values below 4.2 lead to the death of earthworm populations, which are essentially responsible for bioturbation, i.e. the mixing of the upper mineral soil layers with nutrients from the humus layer. But even at base-rich sites that are not prone to acidification, the litter always leaves a part of the hard decomposable organic components (e.g. waxes, tannins, etc.) that lead to an accumulation of carbon over time [23-26].

The progressions of the parameters that characterise the acid/base status appear plausible and comprehensible. The model part that simulates the $\mathrm{N}$ budget appears to have even more model-internal uncertainties.

\section{Sensitivity analysis}

Sensitivity analysis was used to check various parameters of the modelling result for sensitivity by changing the input values. The sensitivity was determined by the change of the result values related to the change of the input values. The sensitivity analysis for the 2005 model results was carried out at 3 sites. These three sites cover approximately the range of all investigation sites with regard to the input data.

The input parameters base saturation and $\mathrm{C} / \mathrm{N}$ ratio in the reference state (bsat_0, CNrat_0) as well as the carbon content in the reference state (Cpool_0) were increased or decreased step by step, whereby the values were initially changed by only a few percentage values and then increased by higher percentage values. Thus, not only the reaction of the results in the narrower range could be observed, but also the development of the values over a larger range. On the basis of the percentage changes of the individual parameters over an entire variation range, the results can be presented in the following sensitivity diagrams.

\section{Carbon content in reference state}

Additional file 4: Figures S15-S17 show the sensitivity of the modelled result parameters to the variation of the parameter Cpool_0. The 3 selected sites cover the carbon content spectrum of all sites. 606: $7091 \mathrm{~g} \mathrm{~m}^{-2} ; 608$ : 14,212 $\mathrm{g} \mathrm{m}^{-2}$; 911: 27,258 $\mathrm{g} \mathrm{m}^{-2}$.

The modelled carbon content in 2005 at all 3 sites was positively linearly proportional to the $\mathrm{C}$ content at the beginning of the simulation in 1920 (= reference state). The maximum variance in 2005 was $4 \%$ with maximum variation of Cpool_0 to 6\%. There are no recognisable differences depending on the height of Cpool_0. The same picture can be seen with the modelled Npool 2005.

The rate of change of the nitrate concentration in the leachate $\left[\mathrm{NO}_{3}\right]$ with variation of Cpool_0 by up to $\pm 6 \%$ was highest at site 911 and ranges from -100 to $+130 \%$. At site 608 , the nitrate concentration changes only insignificantly from -0.25 to $+0.07 \%$ with the same pool variation and not at all at site 606 .

The rate of change of the $\mathrm{Al} / \mathrm{Bc}$ ratio $(\mathrm{Bc}=\mathrm{Ca}+\mathrm{Mg}+\mathrm{K})$ was also highest at site 911, where Cpool_0 was also highest. The rate of change here ranges from -7 to $+5 \%$ from -5 to $+4 \%$ when the Cpool_0 was varied. At site 608 , the $\mathrm{Al} / \mathrm{Bc}$ ratio of $-1 \%$ to $+1.5 \%$ changes only insignificantly with the same pool variation and there are no discernible changes at site 606. In summary, it can be estimated that the higher Cpool_0, the higher the sensitivity of the result parameters to the change in Cpool_0.

\section{$\mathrm{C} / \mathrm{N}$ ratio in reference condition}

The sensitivity of the modelled result parameters to the variation of the parameter CNrat_0 is shown in Additional file 4: Figures S18-S20. The three example sites cover the bandwidth of CNrat_0 with 606: CNrat_0 $=18.5$, 608: CNrat_ $0=20$ and 911: CNrat_0 $=26$.

The variation of the $\mathrm{C} / \mathrm{N}$ ratio (CNrat_0) at the beginning of the simulation (= reference state) has no noticeable influence on the modelled carbon content in 2005 . Regarding the rate of change of the N-Pool with variation of the CNrat_0, a negative linear correlation shows up at all 3 sites. The deflection was greatest at site 606 with the lowest CNrat_0 $(=18.5)$. If the CNrat_0 was varied from -46 to $+35 \%$, the rate of change of the Npool 2005 was $+66 \%$ to $-21 \%$. At site 608 (CNrat_0 $=20)$, 
Table 4 Pearson correlation coefficients for the dependence of base saturation (BS), pH value (pH) and C/N ratio (CN) on temperature (T) and leachate rate (PS)

\begin{tabular}{|c|c|c|c|c|c|c|}
\hline & $\mathrm{BS} / \mathrm{T}$ & $\mathrm{pH} / T$ & $\mathrm{CN} / T$ & BS/PS & $\mathrm{pH} / \mathrm{PS}$ & CN/PS \\
\hline LII-606 & -0.50 & -0.16 & -0.56 & 0.09 & 0.44 & -0.03 \\
\hline LII-608 & -0.58 & 0.44 & -0.69 & 0.77 & -0.55 & 0.86 \\
\hline LII-911 & -0.63 & -0.50 & -0.70 & 0.92 & 0.79 & 0.96 \\
\hline LII-1202 & -0.69 & -0.55 & -0.73 & 0.71 & 0.57 & 0.72 \\
\hline IM Neuglobsow & -0.66 & 0.10 & -0.66 & 0.66 & -0.16 & 0.67 \\
\hline BÜK346131 & -0.69 & -0.71 & -0.68 & 0.89 & 0.93 & 0.88 \\
\hline BÜK344231 & -0.73 & 0.86 & -0.69 & 0.42 & -0.49 & 0.40 \\
\hline BÜK351931 & 0.88 & 0.96 & -0.71 & -0.48 & -0.53 & 0.39 \\
\hline LII-1405 & -0.69 & 0.15 & -0.74 & 0.40 & -0.21 & 0.38 \\
\hline LII-1602 & -0.44 & 0.57 & -0.85 & 0.59 & -0.56 & 0.97 \\
\hline LII-1605 & -0.48 & -0.56 & -0.80 & 0.25 & 0.54 & 0.20 \\
\hline LII-1609 & -0.39 & 0.48 & -0.85 & -0.44 & -0.65 & -0.23 \\
\hline W.I.E. Biesenthal & -0.55 & 0.04 & -0.78 & -0.56 & -0.14 & -0.70 \\
\hline W.I.E. Kahlenberg & 0.17 & 0.47 & -0.80 & -0.42 & -0.12 & -0.12 \\
\hline W.I.E. Peitz & -0.17 & 0.66 & -0.74 & -0.79 & 0.22 & -0.51 \\
\hline
\end{tabular}

if the CNrat_0 varies from -25 to $+25 \%$, the change rate of the Npool 2005 was $+29 \%$ to $-20 \%$. At site 911 $\left(\mathrm{CNrat} \_0=26\right)$ the maximum variation of CNrat_0 by $\pm 19 \%$ generated a deviation of the N-Pool from -12 to $+16 \%$.

The rate of change of the nitrate concentration in the leachate $\left[\mathrm{NO}_{3}\right]$ with variation of CNrat_0 by up to $\pm 19 \%$ was highest at site 911 and ranges from -100 to $+25 \%$. Thus an increase of CNrat_0 produces a decrease of the nitrate concentration, which was to be expected. A decrease in CNrat_0 leads to an increase in nitrate concentration, which was also plausible. However, there seems to be no directional correlation. At site 608, a CNrat_0 variation between -10 and $+25 \%$ does not change the nitrate concentration, but a change of CNrat_0 from -0.10 to $-25 \%$ increases the nitrate concentration steeply to $1200 \%$. Nothing changes at site 606 . The variability of $\left[\mathrm{NO}_{3}\right]$ as a function of CNrat_0 was very high.

The CNrat_0 has a negative proportional influence on the variance of the $\mathrm{Al} / \mathrm{Bc}$ ratio. The rate of change was particularly high at site 911 with the highest CNrat_0, where the $\mathrm{Al} / \mathrm{Bc}$ ratio fluctuates from 40 to $-15 \%$ if the CNrat_0 was varied by $\pm 19 \%$. At sites 608 and 606 with significantly lower CNrat_0, variation of CNrat_0 from -10 to $+40 \%$ initially does not change anything, but when CNrat_0 decreases from -10 to $-45 \%, \mathrm{Al} / \mathrm{Bc}$ rises steeply to $62 \%$ (site 608) and 14\% (site 606), respectively.

\section{Base saturation in reference state}

The sensitivity of the modelled result parameters to the variation of the parameter bsat_0 is shown in Additional file 4: Figures S21-S23. Accordingly, the rate of change of the $\mathrm{pH}$ value shows a strong positive proportional correlation to the variation of the base saturation at the beginning of the simulation (= reference state) at all sites in the form of a typical error function. At site 606, which was attributed to the carbonate buffer with a very high base saturation in the reference state and in the current state, the $\mathrm{pH}$ value changes by $-34 \%$ if the bsat_0 was changed by up to $100 \%$. Site 608 was and was very pHstable in the middle area of the exchanger buffer. Even if the bsat_0 was varied by $-100 \%$ to $+150 \%$, the $\mathrm{pH}$ value only changed from a maximum of $-8 \%$ to $+23 \%$. Also at site 911, which was and remains in the exchanger buffer, a positive proportional error function was shown with variation of bsat_0 from -100 to $+300 \%$, whereby the $\mathrm{pH}$ value deviates only to a maximum of $-5 \%$ downwards, but to a maximum of $+22.5 \%$ upwards.

The change of the $\mathrm{Al} / \mathrm{Bc}$ ratio $(\mathrm{Bc}=\mathrm{Ca}+\mathrm{Mg}+\mathrm{K})$ as a function of the variation of bsat_0 runs in steps. As long as a limit value of bsat_0 was not fallen below (obviously at the transition from the exchanger buffer to the aluminium buffer), the value of $\mathrm{Al} / \mathrm{Bc}$ close to 0 does not change with variation of bsat_0 (sites 606 and 608). If this limit value of bsat_0 was undershot, $\mathrm{Al} / \mathrm{Bc}$ increases steeply in negative proportion. This was demonstrated by site 911 with variation of bsat_0 from -10 to $-100 \%$ with an increase of $\mathrm{Al} / \mathrm{Bc}$ from 0 to $1820 \%$.

\section{Temperature and leachate rate}

In order to investigate how sensitive the VSD+ model reacts to changes in the climate parameters, the time series of the soil parameters base saturation (BS), $\mathrm{pH}$ 
value $(\mathrm{pH})$ and $\mathrm{C} / \mathrm{N}$ ratio $(\mathrm{CN})$ resulting from the modelling were investigated with regard to their correlation to the time series of the climate parameters temperature $(T)$ and leachate rate (PS). A clear (negative) correlation $(p<0.001)$ was only found for the dependence of the $\mathrm{C} / \mathrm{N}$ ratio on the temperature (Table 4). The other two soil chemical parameters $\mathrm{BS}$ and $\mathrm{pH}$ were not calculated in the model as a function of climate parameters. This result was to be expected and was plausible.

A comparison of the time series of soil chemical parameters from 2010 to 2070 nevertheless shows obvious differences depending on the climate scenario at only a few sites. The absolute differences in the $\mathrm{C} / \mathrm{N}$ ratio depending on the temperature forecasts of the climate scenarios RCP2.6 and RCP8.5 are also only minor. The W.I.E. Peitz site has the largest temperature variance between RCP2.6 and $\mathrm{RCP} 8.5(1.7 \mathrm{~K})$. However, the $\mathrm{C} / \mathrm{N}$ ratio only differs by $0.6 \% \mathrm{C} / \% \mathrm{~N}$.

\section{Conclusion}

The sensitivity analysis shows the expected correlations between input data and results. Both the direction of the correlation and the extent of the rates of change with variation of the input data are plausible and scientifically reasonable.

\section{Validation and evaluation of results}

Based on quantitative criteria outlined by Jenssen et al. $[8,18]$, Schlutow et al. $[27,28]$ and Schröder et al. [11, $12]$, the modelling results were interpreted by two experts with respect to recommendations for measures to increase the adaptability of forest ecosystems as follows ("Relevance of modelling results for the projection of possible future ecosystem conditions and for related forest management options" section).

The comparison of the two expert assessments of ecosystem types in their current forest ecosystem type (cEsT) shows complete agreement (Table 5, column 3). This results from the good information available on the current value ranges of the relevant site factors which was based on measured values. The assessment of potential forest ecosystem type (pEsT) also shows a high degree of agreement (87\%). Differences in the assessment of pEsT at 2 sites (Table 5, column 2) result from the different state of knowledge of the local situation. While the first mentioned pEsT of ICP Forests Level II site 1202 and W.I.E site Peitz were derived solely from the results of the dynamic modelling, the estimation of the second mentioned pEsT of these sites was based on many years of local knowledge with corresponding vegetation and site analyses. The uncertainties of dynamic modelling were pointed out in "Discussion" section. However, pEsT estimates of both experts were not very far apart and are within the discretion of the two experts estimate.

The differences with regard to the development of possible future ecosystem types in dependence on Scenarios RCP 2.6 and 8.5 (Table 5, columns 4 and 5) assuming different climate and deposition scenarios are predominantly significant and show a clear trend: the first mentioned ecosystem types (expert 1) show worse site conditions in the future than the second mentioned ones (expert 2). The development of the humus class was estimated less favourable and the proportion of coniferous tree species higher. This assessment results from the fact that the first mentioned future ecosystem types were derived from the results of the VSD+ modelling. In the estimation of the second ecosystem types (expert 2), on the other hand, the influence of the proposed silvicultural adaptation measures was already taken into account, so that the forecasts of forest development are correspondingly more favourable.

The investigation shows that the dynamic modelling of abiotic site parameters has delivered plausible results. There was always some leeway in the interpretation of the results with regard to the geochemically induced vegetation development. To reduce the scope of interpretation, the coupling of the geochemical-dynamic model VSD+ with a dynamic vegetation model would be helpful. Nevertheless, the modelling approach presented contributes to the implementation of the European Biodiversity Strategy which is intended to be based on thorough assessments of ecosystem conditions. The approach to dynamically model soil chemical conditions under the influence of climate change is part of a complex methodology to address ecosystem integrity in the framework of the European Biodiversity Strategy. In addition to dynamic modelling of soil chemical properties, the methodology includes a statistically based classification of ecosystem types, including their GIS-based mapping, as well as a set of rules for objectively classifying the deviations of an observed or predicted ecosystem state compared to a quantified reference state. The methodology is generic in that it is based on publicly available environmental monitoring data from the competent authorities and is fully transparent and thus reproducible. This and all (sub-)methodologies have been published and are accessible in detail. In this respect, the presented methodology is unique so far and should therefore be published.

\section{Conclusions}

The obtained results indicate a decrease in the $\mathrm{C}$ content and a decrease in $\mathrm{C} / \mathrm{N}$ in soils. These findings are consistent with a comprehensive review by Jonard et al. [2]. A certain limitation of the research is the number of 


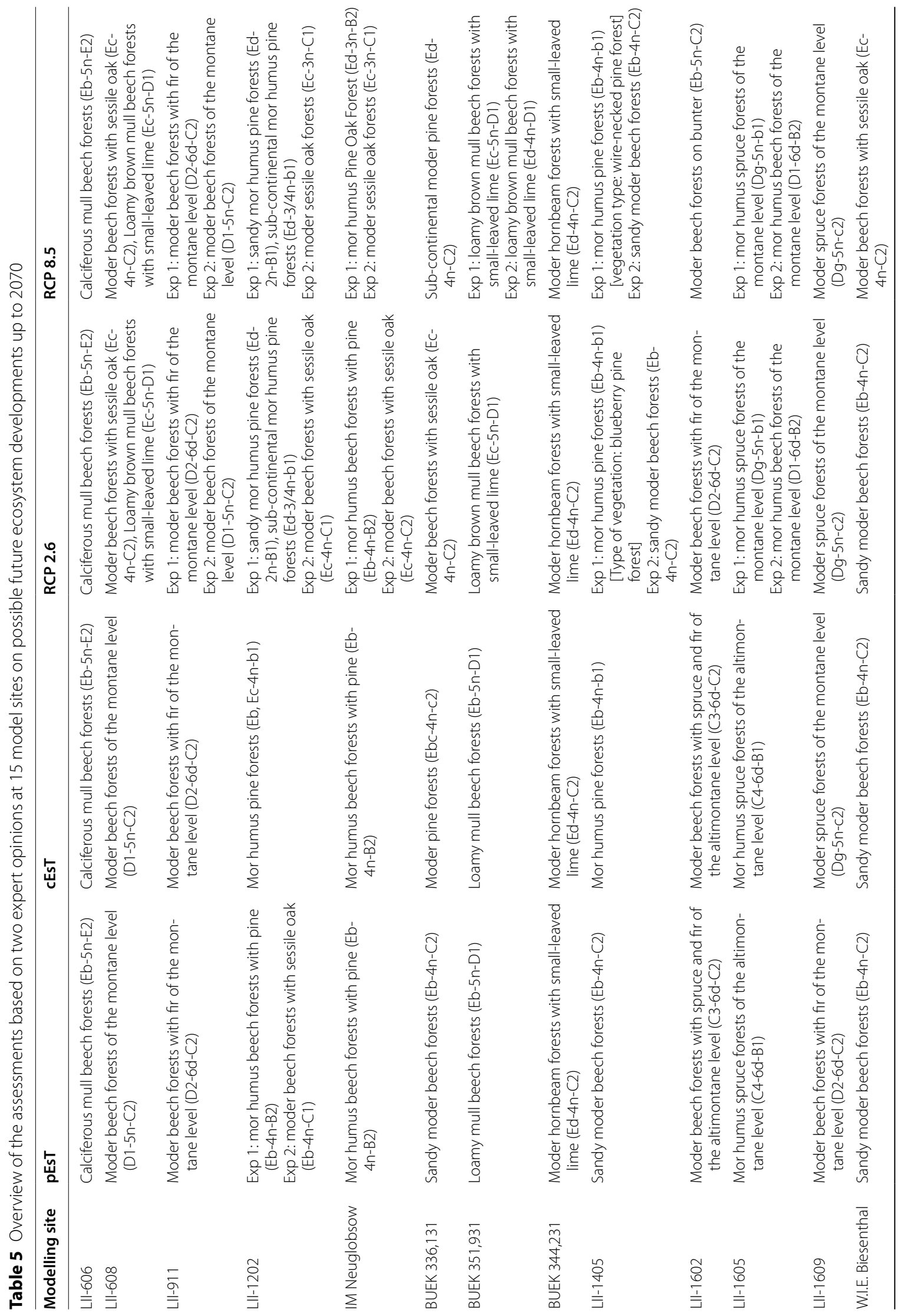




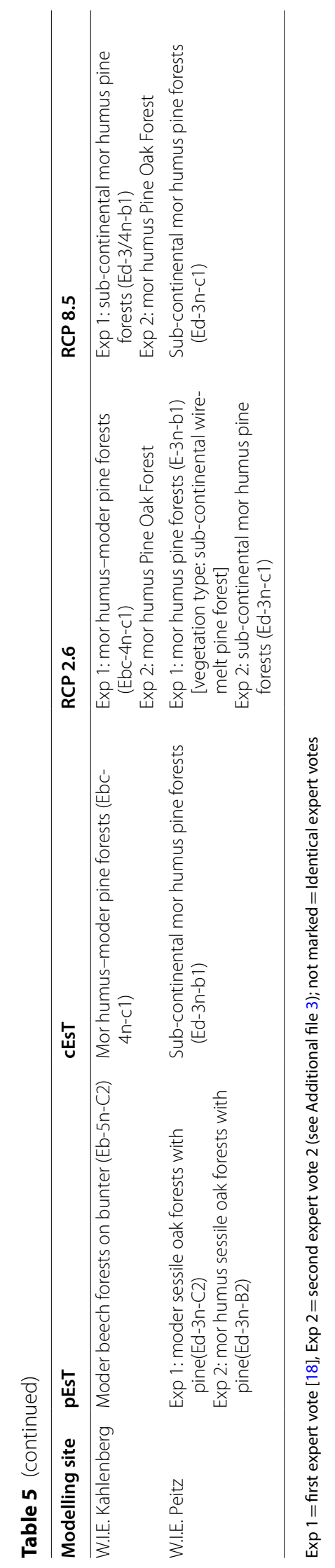


research plots and the availability of long-term observation series. However, this is a common problem, as it is difficult to make available spatially and timely consistent and methodically harmonised data on vegetation and soils derived by long-term monitoring. According to Jonard et al. and Sardans et al. [3], N deposition may be associated with a decrease in $\mathrm{P}$ and $\mathrm{K}$ in leaves and soil, resulting in soil nutrient imbalance. Atmospheric $\mathrm{N}$ deposition may accelerate tree growth, but deterioration of mineral nutrition of fast-growing stands is recently observed, particularly in Europe [2], which in the future may reduce forest ecosystem stability [3].

From the results of soil modelling by example of 15 representative forest sites in Germany the following trends can be summarised:

1. There are no continuous linear correlations between the level of acidifying or eutrophying inputs and the course of soil parameter values. This is plausible because ecosystems generally have a type-specific resilience that enables them to compensate for impairments within a tolerable range. Only when this range is exceeded or undercut by the impacts does a relatively rapid and drastic change in parameter values occur. This explains the step-like courses of the resulting time series of the soil parameters.

2. This was particularly evident from the modelling results at sites where the exchanger buffer has been consumed by high acid deposition and low acid neutralisation capacity in the reference state and the aluminium buffer was now effective. If the $\mathrm{pH}$ value $\left(\mathrm{H}_{2} \mathrm{O}\right)$ falls below 4.2, the base saturation drops abruptly to values of up to $3 \%$.

3. The high $\mathrm{N}$ deposition induced $\mathrm{N}$ saturation at all sites (with the exception of ICP IM Neuglobsow). In the current state there was no recognisable relationship between $\mathrm{C} / \mathrm{N}$ ratio and humus class any more. There was no linear (negative) correlation between $\mathrm{N}$ deposition height and $\mathrm{C} / \mathrm{N}$ ratio at these sites. Also, for this parameter there seems to be a step-wise decrease depending on the accumulation capacity of the soil and vegetation.

4. According to the modelling results, an increase in the $\mathrm{N}$-content in the soil was only slight, if at all. On the other hand, the nitrate concentration in the leachate increases in correlation to the $\mathrm{N}$ deposition and decreases again from 1985 to 2009 and also until 2070 according to the deposition scenarios. Thus, the drastic decrease of the $\mathrm{C} / \mathrm{N}$ ratio at all study sites was also progressively due to the significant decrease of the $\mathrm{C}$ content until 2070.A clear (negative) correlation was found for the dependence of the $\mathrm{C} / \mathrm{N}$ ratio on the temperature development in connection with climate change.

5. The reference state of the base saturation has a decisive influence on the course of base saturation and $\mathrm{pH}$ value. If base saturation 1920 was around $60 \%$ or higher, the decrease due to acid deposition, regardless of their amount, was rather low or non-existent.

6. The continuing acidification at all study sites even after 2010, even with strongly declining $\mathrm{S}$ and $\mathrm{N}$ deposition, was due in particular to the fact that the deposition of basic cations will fall far below the 1920 level from 2010 onwards. The basic fly ash from coal and wood combustion was largely eliminated. The equipping of industrial plants with dust filters has already led to a significant reduction in the base input by 2010 .

7. The base loss due to exchange at the soil colloids and their leaching was associated with the loss of the adsorption capacity of carbon at the soil colloids, so that it was likely that the $\mathrm{C}$ stock due to release and soil respiration at all study sites decreased continuously until 2010. The predicted air temperature rise of the climate scenarios until 2070 will also cause a decrease of the carbon content in the future, caused by the increasing activity of decomposing soil organisms.

8. The validation shows that the dynamic modelling of abiotic site parameters has delivered plausible results at the investigated sites. The applicability of the results can be demonstrated. Thus, the evaluation of the time series of soil and climate parameters resulted in forest ecosystem types that are capable of self-regeneration in the future under the conditions of air pollutant inputs and climate change. These results lead to scientifically justified proposals for site-specific forest conversion with the aim of developing stable and resilient forests with high biodiversity and ecological functionality.

The question of whether and to what extent ecosystem types will change in the future under the influence of $\mathrm{N}$ input scenarios and climate change, or are already changed today compared to the reference state, cannot be concluded generally on the basis of the few sites analysed. However, this would be a decisive prerequisite for the development of regionally differentiated proposals for adaptation measures, e.g. in forestry, to climate change and soil chemical changes.

\footnotetext{
Abbreviations

Al: Aluminium; $\mathrm{Al} /(\mathrm{Ca}+\mathrm{Mg}+\mathrm{K})$ ratio: Ratio of aluminium to the sum of base cations $\mathrm{Ca}+\mathrm{Mg}+\mathrm{K}$; BDF: Long-term soil monitoring in Germany; BERN: Model and database "Bioindication for Ecosystem Regeneration towards Natural conditions"; bsat_0: Base saturation in reference state of the soil in the steady state of the nutrient regime; BÜK1000N: Reference soil profile of the land use-specified soil
} 
map 1:1,000,000 Germany; ${ }^{\circ} \mathrm{C}$ : Degree Celsius; Ca: Calcium; Ca_we, Mg_we, K_we, Na_we:Weathering rate of $\mathrm{Ca}, \mathrm{Mg}, \mathrm{K}, \mathrm{Na}$ [eq $\mathrm{m}^{-2} \mathrm{a}^{-1}$ ]; Ca_dep, Mg_dep, K_dep: Atmospheric deposition rate of $\mathrm{Ca}-, \mathrm{Mg}^{-}$, and $\mathrm{K}$-compounds [eq $\mathrm{m}^{-2} \mathrm{a}^{-1}$ ]; $\mathrm{CEC}$ Effective cation exchange capacity; Clf: Carbon litterfall flux [ $\left[\mathrm{g} \mathrm{m}^{-2} \mathrm{a}^{-1}\right]$; C/N: Carbon/nitrogen ratio; CNrat_0: C/N ratio in reference state of the soil in the steady state of the nutrient regime; C horizon: Substratum; CEsT: Current forest ecosystem type (for specification of cEsT see text and tables in the manuscript); Clay_ct: Clay content; Cpool_0: Carbon stock in reference state; Corg: Organic carbon; EBc: Ratio of base cations $\mathrm{Ca}+\mathrm{Mg}+\mathrm{K}$ in soil solution; eq: Equivalent of hydrogen ions; EsT: Forest ecosystem type (for specification of EsT see text and tables in the

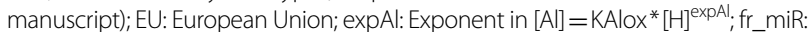
Reduction factors of mineralisation; $\mathrm{G}$ horizon: Groundwater horizon; Gr horizon: Oxygen-free (reduced) groundwater horizon; H: Hydrogen; ICP Forests: International Cooperative Program on Assessment and Monitoring of Air Pollution Effects on Forests; ICP IM: International Cooperative Program on Integrated Monitoring of Air Pollution Effects on Ecosystems; K: Potassium; ' ${ }^{\circ}$ : Degree Kelvin; KHBc: Logarithmic GAPON exchange coefficient $\mathrm{H}$ to $\mathrm{Ca}+\mathrm{Mg}+\mathrm{K}$; KAlBc: Logarithmic GAPON exchange coefficient Al to $\mathrm{Ca}+\mathrm{Mg}+\mathrm{K}$; Mg: Magnesium; MetHyd: The VSD subroutine "MetHyd" was a hydrological model for calculating the daily evapotranspiration rate, soil moisture and temperature, and leachate rate [17]; N: Nitrogen; NOx_dep: Atmospheric deposition rate of oxidised nitrogen compounds [eq $\mathrm{m}^{-2} \mathrm{a}^{-1}$ ]; NH3_dep: Atmospheric deposition rate of ammonia [eq $\mathrm{m}^{-2} \mathrm{a}^{-1}$ ]; $\mathrm{pCO}_{2} \mathrm{fac}: \mathrm{CO}_{2}$ pressure in the soil solution (given as a multiple of $\mathrm{pCO}_{2}(\mathrm{~atm})$ in air); $\mathrm{Na}$ : Sodium; NIf: Nitrogen litterfall flux [ $\mathrm{g} \mathrm{m}^{-2} \mathrm{a}^{-1}$ ]; P horizon: Claystone; percol: Leachate rate $\left[\mathrm{m}^{3} \mathrm{a}^{-1}\right]$; $\mathrm{pEST}$ : Potential forest ecosystem type; $\mathrm{pH}\left(\mathrm{H}_{2} \mathrm{O}\right)$-value:Value of the negative decadic logarithm of hydrogen concentration measured in water; PS: Precipitation surplus [ $\mathrm{m}^{3} \mathrm{~m}^{-2} \mathrm{a}^{-1}$ ]; OM: Organic mass contents; RCP: Representative Concentration Pathways; RCOOmod: Organic acid dissociation model option: $=0$ : Oliver model; $=1$ : monoprotic organic acid $;<0$ : NO organic acids simulated (default); CRCOO: Concentration of organic acids ( $\left.\mathrm{m}^{*} \mathrm{DOC}\right)\left(\mathrm{mol} / \mathrm{m}^{3}\right)$; RCOOpars: Parameters for organic acid dissociation model: monoprotic model 1 pK; Oliver model [31] values are $a=0.96, b=0.9$ and $c=0.039$; rf_denit: Reduction of denitrification rates due to moisture and temperature (-); rf_nit: Reduction factor of nitrification rates due to moisture and temperature (-); S: Sulphur; S_dep: Atmospheric deposition rate of sulphur compounds [eq $\mathrm{m}^{-2} \mathrm{a}^{-1}$ ]; STAR: Statistical regional climate model; Sr horizon: Oxygen-free (reduced) backwater horizon; theta: Water content of the soil; Total $C$ pool: Total amount of $C$ in top layer per unit area; Total $\mathrm{N}$ pool: Total amount of $\mathrm{N}$ in top layer per unit area; TempC: Temperature in degree Celsius; VSD+:Very Simple Dynamics Soil model, version 5.3.1 [15], CCE 2012; [16]; Y horizon: Horizon filled with reductgas.

\section{Supplementary Information}

The online version contains supplementary material available at https://doi.org/ 10.1186/s12302-021-00526-7.

Additional file 1. Data used and characteristics of modelling regions and modelling sites.

Additional file 2. Site-specific input data for VSD+ modelling.

Additional file 3. Soil modelling results for the sites Nos. 2-15.

Additional file 4. Figures of modelling results.

\section{Acknowledgements}

We thank Gudrun Schütze (Federal Environment Agency) for her constructive professional support of the project.

\section{Authors' contributions}

WS headed the investigation and drafted the manuscript. AS performed the dynamic modelling. MJ developed the ecosystem classification. SN performed the data management. All authors read and approved the final manuscript.

\section{Funding}

Open Access funding enabled and organized by Projekt DEAL. The studies were financed by the Federal Environment Agency.

Availability of data and materials

See Jenssen et al. [29, 30].

\section{Declarations}

Ethics approval and consent to participate

Not applicable.

\section{Consent for publication}

Not applicable.

\section{Competing interests}

The authors declare that they have no competing interests.

\section{Author details}

${ }^{1}$ Öko-Data Ökosystemanalyse und Ökosystemdatenmanagement, Lessingstraße 16, 16356 Ahrensfelde, Germany. ${ }^{2}$ Chair of Landscape Ecology, University of Vechta, P.O.B. 1553, 49364 Vechta, Germany.

Received: 18 April 2021 Accepted: 2 July 2021

Published online: 04 August 2021

\section{References}

1. Bobbink R, Hicks K, Galloway J, Spranger T, Alkemade R, Ashmore M, Bustamante M, Cinderby S, Davidson E, Dentener F, Emmett B, Erisman JW Fenn M, Gilliam F, Nordin A, Pardo L, De Vries W (2010) Global assessment of nitrogen deposition effects on terrestrial plant diversity: a synthesis. Ecol Appl 20:30-59

2. Jonard M, Fürst $A$, Verstraeten $A$, Thimonier $A$, Timmermann $V$, Potočić $N$, Waldner P, Benham S, Hansen K, Merilä P, Ponette Q, de la Cruz AC, Roskams P, Nicolas M, Croisé L, Ingerslev M, Matteucci G, Decinti B, Bascietto M, Rautio $P$ (2015) Tree mineral nutrition is deteriorating in Europe. Glob Change Biol 21(1):418-430. https://doi.org/10.1111/gcb.12657

3. Sardans J, Alonso R, Janssens IA, Carnicer J, Vereseglou S, Rillig MC, Fernández-Martínez M, Sanders TGM, Peñuelas J (2016) Foliar and soil concentrations and stoichiometry of nitrogen and phosphorous across European Pinus sylvestris forests: relationships with climate, $\mathrm{N}$ deposition and tree growth. Funct Ecol 30:676-689. https://doi.org/10.1111/1365-2435.12541

4. Van Dobben $\mathrm{H}$, de Vries W (2010) Relation between forest vegetation: atmospheric deposition and site conditions at regional and European scales. Environ Pollut 158:921-933

5. Gaudio N, Belyazid S, Gendre X, Mansat A, Nicolas M, Rizzetto S, Sverdrup $H$, Probst A (2014) Combined effect of atmospheric nitrogen deposition and climate change on temperate forest soil biogeochemistry: a modeling approach. Ecol Model 306:24-34

6. De Vries W, Wamelink GWW, van Dobben H, Kros J, Reinds GJ, Mol-Dukstra JP, Smart SM, Evans CD, Rowe EC, Belyazid S, Sverdrup H, van Hinsberg A, Posch $M$, Hettelingh JP, Spranger T, Bobbink R (2010) Use of dynamic soil-vegetation models to assess impacts of nitrogen deposition on plant species composition: an overview. Ecol Appl 20:60-79

7. Maes J, Teller A, Erhard M, Grizzetti B, Barredo Jl, Paracchini ML, Condé S, Somma F, Orgiazzi A, Jones A, Zulian A, Vallecilo S, Petersen JE, Marquardt D, Kovacevic V, Abdul Malak D, Marin Al, Czúcz B, Mauri A, Loffler P, Bastrup-Birk A, Biala K, Christiansen T, Werner B (2018) Mapping and assessment of ecosystems and their services: an analytical framework for ecosystem condition. Publications office of the European Union, Luxembourg, pp 1-75

8. Jenssen M, Hofmann G, Nickel S, Pesch R, Riediger J, Schröder W (2013) Bewertungskonzept für die Gefährdung der Ökosystemintegrität durch die Wirkungen des Klimawandels in Kombination mit Stoffeinträgen unter Beachtung von Ökosystemfunktionen und -dienstleistungen [Assessment concept for the threat to ecosystem integrity posed by the effects of climate change in combination with substance deposition, taking into account ecosystem functions and services]. UBA-Texte 87(2013):1-381

9. Jenssen M, Schröder W, Nickel S (2015) Typisierung von Wald- und Forstökosystemen als Grundlage zur Einstufung ihrer Integrität. Integrität von Wald- und Forstökosystemen unter dem Einfluss von Klimawandel und atmosphärischen Stickstoffeinträgen-Teil I. Naturschutz und Landschaftsplanung 47(12):391-399

10. Nickel S, Schröder W, Jenssen M (2015) Veränderungen deutscher Wälder durch Klimawandel und Stickstoffdeposition. Schweiz Z Forstwes 166(5):325-334 
11. Schröder W, Nickel S, Jenssen M, Riediger J (2015) Methodology to assess and map the potential development of forest ecosystems exposed to climate change and atmospheric $\mathrm{N}$ deposition: a pilot study in Germany. Sci Total Environ 521-522:108-122

12. Schröder W, Nickel S, Jenssen M, Hofmann G, Schlutow A, Nagel H-D, Burkhard B, Dworczyk C, Elsasser P, Lorenz M, Meyerhoff J, Weller P, Altenbrunn K (2019) Anwendung des Bewertungskonzepts für die Ökosystemintegrität unter Berücksichtigung des Klimawandels in Kombination mit Stoffeinträgen [Application of the ecosystem integrity assessment concept for climate Change in combination with atmospheric deposition]. 3 Vols. UBA-Texte 97/2019:1-504, UBA-Texte 98/2019:1-344, UBA-Texte 99/2019:3:1-234

13. Orlowsky B, Gerstengarbe F-W, Werner P (2008) A resampling scheme for regional climate simulations and its performance compared to a dynamical RCM. Theor Appl Climatol 92:209-223

14. IPCC (2014) Climate change 2014: synthesis report. Contribution of working groups I, II and III to the fifth assessment report of the Intergovernmental Panel on Climate Change [Core writing team: R.K. Pachauri and L.A. Meyer (eds)]. IPCC, Geneva, Switzerland, pp 1-151

15. Bonten LTC, Reinds GJ, Posch M (2016) A model to calculate effects of atmospheric deposition on soil acidification, eutrophication and carbon sequestration. Environ Model Softw 79:75-84

16. Posch M, Reinds GJ (2009) A very simple dynamic soil acidification model for scenario analyses and target load calculations. Environ Model Softw 24:329-340

17. Reinds GJ, Bonten L, Mol-Dijkstra JP, Wamelink GWW, Goedhart P (2012) Combined effects of air pollution and climate change on species diversity in Europe: First assessments with VSD+ linked to vegetation models. In: Posch M, Slootweg J, Hettelingh J-P (eds) Modelling and mapping of atmospherically-induced ecosystem impacts in Europe. CCE Status Report, 2012, Bilthoven, The Netherlands, pp 49-62

18. Jenssen M, Nickel S, Schütze G, Schröder W (2021) Reference states of forest ecosystem types and feasibility of biocenotic indication of ecological soil condition as part of ecosystem integrity and services assessment. Environ Sci Eur 33(18):1-18. https://doi.org/10.1186/s12302-021-00458-2

19. Schlutow A, DirnböckT, Pecka T, Scheuschner T (2015) Use of an empirical model approach for modelling trends of ecological sustainability. In: De Vries W, Hettelingh J-P, Posch M (eds) Critical Loads and dynamic risk assessments: nitrogen, acidity and metals in terrestrial and aquatic ecosystems. Springer, New York, pp 381-402

20. Schlutow A, Jenssen M, Nickel S, Schröder W (2019) Dynamische Modellierung von Bodenmerkmalen an Ökosystemtypen-repräsentativen Standorten in Deutschland als Grundlage für Projektionen zukünftiger Ökosystementwicklung. Handbuch der Umweltwissenschaften - 27. Erg. Lfg. 02/19. https://doi.org/10.1002/9783527678525.hbuw2019004

21. Schröder W, Nickel S (2020) Research data management as an integral part of the research process of empirical disciplines using landscape ecology as an example. Data Sci J 19(26):1-14. https://doi.org/10.5334/dsj-2020-026

22. Grüneberg E, RiekW, Schöning I, Evers J, Hartmann P, Ziche D (2017) Kohlenstoffvorräte und deren zeitliche Veränderungen in Waldböden. In: Wellbrock, $\mathrm{N}$, Bolte A, Flessa H (Hg.) Dynamik und räumliche Muster forstlicher Standorte in Deutschland. Ergebnisse der Bodenzustandserhebung im Wald 20062008. Thünen Report 43, S. I-183 bis I-209 [Carbon stocks and their temporal changes in forest soils. In: Wellbrock N, Bolte A, Flessa H (eds) Dynamics and spatial patterns of forest sites in Germany. Results of the soil condition survey in forests 2006-2008. Thünen Report 43, S. I-183 to I-209]
23. Brinkmann S, Nieder R (2002) Critical Loads für eutrophierenden Stickstoff - Weiterentwicklung des Ansatzes unter besonderer Berücksichtigung der Umsetzung im Boden (Humusschicht) [Critical loads for eutrophic nitrogen-further development of the approach with special consideration of the implementation in the soil (humus layer)]. Braunschweig, pp 1-116

24. Horvath B, Meiwes K-J, Meesenburg H (2011) Stickstoffaustrag und Stickstoffspeicherung in Waldböden bei hohem luftbürtigen Eintrag [ $\mathrm{N}$ discharge and $\mathrm{N}$ storage in forest soils with high airborne input]. AFZ 17:22-24

25. Meiwes K-J, Meesenburg H, Bartens H, Rademacher P, Khanna PK (2002) Akkumulation von Auflagehumus im Solling. Mögliche Ursachen und Bedeutung für den Nährstoffkreislauf [Accumulation of surface layer humus in the Solling. Possible causes and significance for the nutrient cycle]. For Wood 57:428-433

26. Templer PH, Mack MC, Chapin FS, Christenson LM, Compton JE, Crock HD, Currie WS, Curtis CJ, Dail DB, DÁntonio CM, Emmett BA, Epstein HE, Goodale CL, Gundersen P, Hobbie SH, Holland K, Hooper DU, Hungate BA, Lamontagne S, Nadelhoffer KJ, Osenberg CW, Perakis SS, Schleppi P, Schimel J, Schmidt IK, Sommerkorn M, Spoelstra J, Tietema A, Wessel WW, Zak DR (2012) Sinks for $\mathrm{N}$ deposition in terrestrial ecosystems. A meta-analysis of $15 \mathrm{~N}$ tracer field studies. Ecology 93(8):1816-1829

27. Schlutow A, Kraft P, Weigelt-Kirchner R (2007) Veränderungen der potenziell natürlichen Vegetation im Zuge des Klimawandels im Freistaat Sachsen. Endbericht zum Forschungsvorhaben Nr. 40200317 im Auftrag des Staatsbetriebes Sachsenforst [Changes in potentially natural vegetation due to climate change in the Federal State of Saxony, Germany. Final report of the research project No. 40200317 on behalf of the Staatsbetriebes Sachsenforst. Graupa. Manuscript printing]

28. Schlutow A, Scheuschner T, Heinzel L, Schlutow M (2014) Anpassung von Klimagliederung und Leitwaldgesellschaften an den Klimawandel in Mecklenburg-Vorpommern. Projekt im Auftrag von Landesforst Mecklenburg-Vorpommern [Adaptation of climate structure and dominating forest communities to climate change in Mecklenburg-Western Pomerania. Project commissioned by Landesforst Mecklenburg-Vorpommern], Germany, pp $1-114$

29. Jenssen M, Nickel S, Schröder W (2019) Einstufung der Ökosystemintegrität von Wäldern und Forsten Deutschlands auf Grundlage quantifizierter Indikatoren, Link zu Forschungsdaten und wissenschaftlicher Software [Classification of the ecosystem integrity of German forests based on quantified indicators, link to research data and scientific software] (Version v1). ZENODO. https://doi.org/10.5281/zenodo.2606380

30. Jenssen M, Nickel S, Schröder W (2019) 61 Referenzzustände zur Beurteilung der ökologischen Integrität von Wald- und Forstökosystemen, Link zu Forschungsdaten [Reference conditions for assessing the ecological integrity of forest ecosystems, link to research data] (Version v1). ZENODO. https://doi. org/10.5281/zenodo.2582888

31. Oliver BG, Thurman EM, Malcolm RL (1983) The contribution of humic substances to the acidity of colored natural waters. Geochim Cosmochim Acta 47:2031-2035

\section{Publisher's Note}

Springer Nature remains neutral with regard to jurisdictional claims in published maps and institutional affiliations. 